\title{
Usefulness of a freshwater macrophyte (Potamogeton pusillus) for an environmental risk assessment in a multi-source contaminated basin.
}

\author{
Lidwina Bertrand a , Magdalena Victoria Monferrán a , María Eugenia Valdés a, b, \\ María Valeria Amé a, * \\ ${ }^{a}$ Centro de Investigaciones en Bioquímica Clínica e Inmunología - CIBICI, Facultad de Ciencias Químicas, CONICET, UNC, Haya de La Torre Esq. Medina \\ Allende, 5000, Córdoba, Argentina \\ b Instituto de Ciencia y Tecnología de Alimentos Córdoba - ICYTAC, Facultad de Ciencias Químicas, CONICET, UNC, Ciudad Universitaria, Av. Juan Filloy s/n, \\ 5000, Córdoba, Argentina
}

\section{H I G H L I G H T S}

- Potamogeton pusillus proved to be a good tool for active biomonitoring.

- Macrophyte stress was associated with $\mathrm{Cr}, \mathrm{Cu}, \mathrm{Cd}, \mathrm{Pb}$ and $\mathrm{Al}$ concentrations.

- Macrophyte stress was associated with total pharmaceuticals concentration in water.

- $\mathrm{Hg}$ in sediments, $\mathrm{Pb}, \mathrm{Al}, \mathrm{As}, \mathrm{B}, \mathrm{Hg}$ in water, surpassed environmental guidelines.

- First report of integrated biomarker response for a macrophytes active biomonitoring.

\section{A R T I C L E I N F O}

\section{Article history:}

Received 31 October 2018

Received in revised form

26 January 2019

Accepted 5 February 2019

Available online 6 February 2019

Handling Editor: Jim Lazorchak

\section{Keywords:}

Active biomonitoring

Metals

Pharmaceutical compounds

Integrated biomarker response

Aquatic plant

Native species

\section{G R A P H I C A L A B S T R A C T}

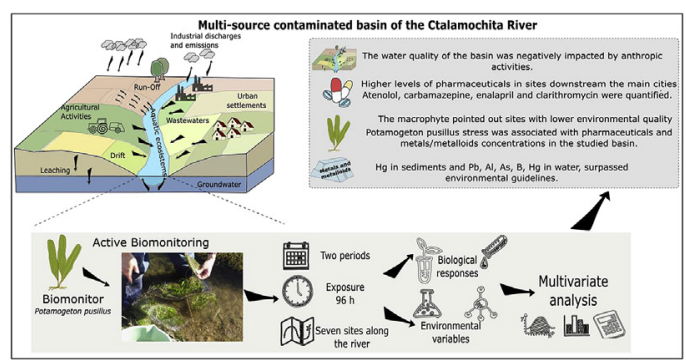

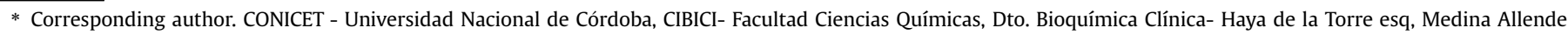
5000, Córdoba, TE, Argentina.

E-mail address: vame@fcq.unc.edu.ar (M.V. Amé).
} 
sediments, increased. Finally, the obtained results indicate that the use of $P$. pusillus in combination with chemical analysis could be considered a promising tool for environmental management of aquatic ecosystems contaminated by multi-source.

() 2019 Elsevier Ltd. All rights reserved.

\section{Introduction}

Chemical analysis of the environmental matrices, such as water and sediments, are the most direct approach to reveal the contamination status in the environment. However, it cannot always offer powerful evidence on the integrated impact and the possible toxicity of such toxic compounds on the organisms and ecosystem. In developed countries, current environmental risk assessment practices comprise the integration of chemical and biological measurements, usually through indices, to assess the status of inland and coastal waters as recommended by the Water Framework Directive, established by the European Union (EU; $\mathbf{2 0 0 0 / 6 0 / E C ) . ~ I n ~ c o n s e q u e n c e , ~ s e v e r a l ~ a u t h o r s ~ p r o p o s e ~ o r g a n i s m s ~}$ from numerous taxa as bioindicators of environmental quality (Mertens et al., 2005).

Aquatic plants, including macrophytes, are worldwide distributed organism in numerous aquatic environments, including freshwater ecosystems. They play a key role in wetland biogeochemistry representing the principal living accumulators of contaminants. Besides, they are responsible for the primary production, fulfilling a fundamental trophic role in aquatic ecosystems (O'Brien et al., 2014). Several studies evaluated the biological responses of aquatic plants exposed under controlled conditions to different compounds such as metals (Costa et al., 2018; Xu et al., 2010), pesticides (Garanzini and Menone, 2015) and pharmaceutical compounds (Brain et al., 2004; Kummerová et al., 2016) with the aim to evaluate mainly their usefulness to remove water pollutants or, their sensitivity and ability as bioindicator tools to be used in monitoring programs.

Surveys could be carried out by using either passive or active monitoring. Passive monitoring refers to organisms sampled in local populations whereas active implies the exposure of organisms in sites to be monitored for a period of time. Nevertheless, most of the biomonitoring surveys developed until now have been focused on the passive monitoring methodology, with the use of vertebrates and invertebrates (Ghisi et al., 2017; Ronci et al., 2016; Ruchter and Sures, 2015), as well as some aquatic plants species (Bonanno et al., 2017; Demirezen and Aksoy, 2004; Gonzalez et al., 2013; Harguinteguy et al., 2016; Pérez et al., 2017) as bioindicators. Passive biomonitoring has been widely used for its sampling simplicity, long-term measurements and existing guidelines. Simultaneously, disadvantages have been previously pointed out, including the effective availability of the selected organism at the sampling sites, the variability in the exposure time, age and size of sampled individuals, among others. The active biomonitoring not only avoids mentioned drawbacks but also allows the choice of organisms' origin, the repeatability of exposure, and to predict the cost and duration of experimentation (Besse et al., 2012). Nevertheless, active biomonitoring has been less developed and, in most of the cases, performed with animal species (Ballesteros et al., 2017; Bertrand et al., 2018; Ciliberti et al., 2017; Tan et al., 2018).

The presence of complex pollutants mixtures in aquatic ecosystems requires an expensive chemical analysis if hundreds of pollutants want to be analysed, but also, a significant investment of time. Instead, the development of biomonitoring programs, able to evaluate environmental quality, searches for the lowest cost and quick procedure trying to avoid, as far as possible, the use of animals (Sneddon et al., 2017). To the best of our knowledge, only a few studies tested and reported the usefulness and ability of macrophyte to point out environmental pollution through an active monitoring procedure in a real scenario where a complex mixture of pollutants occurs (Nimptsch et al., 2005).

The Potamogeton genus includes perennial monocotyledonous hydrophytes, with a cosmopolitan distribution (Novara, 2003). Vegetative propagation of Potamogeton occurs via growth and fragmentation of rhizomes and shoots as well as by dormant apex; sexual reproduction has been described for this genus as well (Nichols and Shaw, 1986). The Potamogeton genus is also a good candidate as test species in non-target plant studies for the development of protection guidelines (http://www.iucnredlist. org). Previous studies reported Potamogeton capacity to evidence pollutants exposure under laboratory conditions (Bertrand et al., 2016, 2017; Costa et al., 2018; Monferrán et al., 2009). In a similar way, others authors described the usefulness of Potamogeton in passive monitoring programs, showing to be useful as a biological indicator while evaluating environmental deterioration (Demirezen and Aksoy, 2004; Harguinteguy et al., 2016; Munteanu and Munteanu, 2007). Nevertheless, the ability of Potamogeton, or another macrophyte genus, to reflect environmental degradation associated with multi-sources pollution through short term exposures in active monitoring studies are scarce or unavailable to the extent of our knowledge.

Given this background, the present study proposes to evaluate the ability and usefulness of Potamogeton pusillus to reflect environmental quality through an active biomonitoring procedure, and additionally, to establish the aquatic ecosystems status through risk indexes. To achieve our goal, organisms from a pristine site were exposed during two different seasons in seven river sites with different land uses, and where spatio-temporal variations in pollutants mixture are expected. During each monitoring campaign, water and sediments samples were collected for physicochemical and pollutants determination. In parallel, exposure, defence and damage biomarkers were measured in tissues from exposed organisms. The results of this study were used to obtain a holistic and integrative overview of the studied scenario, and ultimately, to evaluate the usefulness of $P$. pusillus for environmental risk assessment in aquatic systems.

The hypothesis is that Potamogeton pusillus biochemical responses are able to point out sites with higher environmental degradation due to multi-sources pollutants mixtures in river system.

\section{Materials and methods}

\subsection{Reagents and materials}

All reagents were of analytical grade supplied by Sigma-Aldrich, Merck, and Sintorgan (Argentina). Ultra-pure water (Arium 611 UV system, Sartorius) was used to prepare standard solutions, dilutions, and blanks. All materials were appropriately washed to avoid metal and organic contamination. 


\subsection{Study site}

The Ctalamochita River basin (area $3000 \mathrm{~km}^{2}$, Córdoba, Argentina) was proposed as a case of study of human activities impact on an aquatic ecosystem. Ctalamochita River basin is one of the most important water resources of the central Argentinian region. The water quality of the basin decreases from the upper basin located in a mountainous area to a plain area. The river receives waste wasters discharges from industrial and agricultural activities developed along the basin, but also associated with important urban settlements (DiPAS, UNC, 2007; O'Mill, 2012). For the present study, seven monitoring sites were selected according to an expected variation in pollutants mixtures and levels due to different pollution sources (Fig. 1 and Supplementary Material, SM, Table SM1 and Figure SM1). The site located upstream Santa Rosa de Calamuchita town ( $\mathrm{S} 1$, upper basin) was considered as the reference site due to lower anthropogenic activities.

\subsection{Monitoring}

Individuals of South American native macrophyte, P. pusillus, were collected from a reference site located in a tributary (Yuspe River) of the Suquía River upper basin based on an earlier study (Bertrand et al., 2017). Organisms were acclimated during two weeks in glass aquaria filled with $10 \%$ Hoagland's solution, sediments $(1 / 4)$ from the same sampling area, and they were maintained at $25 \pm 1{ }^{\circ} \mathrm{C}$ under a natural light: dark regime.

Acclimated organisms were transported in tanks to monitoring area where groups of 24 macrophytes were deposited at each site in perforated plastic envelopes with an adequate water circulation (SM, Figure SM1). Envelopes were maintained at a depth of $0.5-0.7 \mathrm{~m}$, simulating environments usually colonized by the selected macrophyte species. Organisms were exposed for four days in two sampling campaigns. The exposure period was selected in accordance to previous laboratory testing (Bertrand et al., 2016, 2017). Sampling dates were chosen to take into account the rain seasonality and thermal variation for the proposed basin: cold (July, $\mathrm{CP}$ ) and warm periods (December, WP), according to previous studies (SM, Table SM2; Bertrand et al., 2018; O'Mill, 2012). After exposure, macrophytes were collected, counted, washed three times with ultrapure water, frozen with liquid nitrogen, and kept at $-80^{\circ} \mathrm{C}$ until analysis.

Samples of superficial $(0-15 \mathrm{~cm}$ depth interval) water and sediment were taken at each sample site during both campaigns in appropriate receptacles depending on the analysis to be carried out. Sample collection, containers, stabilization, and transportation to the laboratory, as well as sample storage for physicochemical and metal determinations, were done in accordance with Merlo et al. (2011), while the procedure for pharmaceutical residues determination in water was conducted as described by Valdés et al. (2014). All samples were collected by duplicate.

\subsection{Physicochemical analysis}

\subsubsection{Water}

Portable equipment (WTW, Multiline F/Set 3) was used for in situ water parameters measurement (water dissolved oxygen, $\mathrm{pH}$, temperature, and conductivity) while, nitrate, nitrite, sulphate, total phosphorus, chlorides, ammonium, and total coliform bacteria were measured in water samples according to Pesce and Wunderlin (2000) and APHA (1998). Results were expressed in $\mu g \mathrm{~L}^{-1}$ except $\mathrm{Cl}^{-}$expressed in $\mathrm{mg} \mathrm{L}^{-1}$ and coliform bacteria as the most probable number (MPN) for $100 \mathrm{~mL}$ of water.

\subsubsection{Sediments}

The content of organic matter (COM; APHA, 1998) and pH (Klute, 1986) were determined in sediment samples. For granulometry, samples were dried at $38^{\circ} \mathrm{C}$ up to constant weight. Afterwards, $100 \mathrm{~g}$ of material were weighed and sieved using metallic meshes (IRAM 1501) obtaining following fractions: gravel ( $>2 \mathrm{~mm}$ ), sands ( $>0.075 \mathrm{~mm}$ and $<2 \mathrm{~mm}$ ) and limes and clays $(<0.075 \mathrm{~mm})$. Proportion of each fraction was calculated.

\subsubsection{Pharmaceutical residues determination in water samples}

Thirteen compounds were selected to be studied, considering different therapeutic classes of pharmaceuticals and steroid hormones, as follows: $\beta$-blockers: atenolol (ATE), propranolol (PROP); antibiotics: ciprofloxacin (CIPR), clarithromycin (CLAR); diureticsantihypertensive: enalapril (ENAL); antiepileptic: carbamazepine (CBZ), oxcarbazepine (OXCZ); androgens: androstenedione (AND), testosterone $(\mathrm{T})$, dihydrotestosterone (DHT), methyltestosterone (MT) and estrogens: $17 \beta$-estradiol $\left(E_{1}\right)$, estrone $\left(E_{2}\right)$. Water samples were extracted using a Strata- $X^{\circledR}$ SPE cartridges $(500 \mathrm{mg} / 6 \mathrm{~mL})$ and analysed by high performance liquid chromatography coupled to mass spectrometry using a quadrupole time-of-flight analyzer, with an electrospray ionization source operated in either positive or negative modes (HPLC-ESI-qTOF, Agilent-Bruker Daltonics, Valdés et al., 2014). Quantification was done by external five-point calibration curves run in each sampling batch. Recoveries for each compound, evaluated in river water, ranged from 40 to $83 \%$. The method limit of detection (LOD) ranged from 0.1 to $16 \mathrm{ng} \mathrm{L}^{-1}$.

\subsubsection{Metals and metalloids in water and sediment samples}

Twenty elements, including seventeen metals and three metalloids were selected and quantified in collected samples according to procedure previously described by Bertrand et al. (2018). An elements sequential extraction was carried out with sediment samples with the aim to obtain bioavailable (mobile A1 + mobilisable A2) and pseudo-total (Ps) fractions of metals previous drying $\left(38^{\circ} \mathrm{C}\right)$ and sieving $(63 \mu \mathrm{m}$ acrylic meshes $)$ of them (Supplementary material, SM, Figure SM2). The analysis of water samples and sediments extracts were performed with a Mass Spectrometer Inductively Coupled Plasma (ICP-MS), X Series, Thermo-Elemental X7 series (Thermo Fisher Scientific, Bremen, Germany), equipped with an ASX-100 autosampler (CETAC Technologies, Omaha, NE). AccuStandard ${ }^{\circledR}$ atomic absorption spectrometry standard solution ( $1000 \mathrm{mg} \mathrm{L}^{-1}$ in $2 \%$ nitric acid) was used as stock solution for calibration of metal quantification equipment. Results were expressed in $\mu \mathrm{g} \mathrm{L}^{-1}$ for water samples and $\mu \mathrm{g} \mathrm{g}^{-1}$ dried materials for sediments.

The concentrations of studied elements were determined in triplicate. Quality assurance (QA) and quality control (QC) were performed using certified reference materials (CRMs) for water: NIST 1640, and NIST 1643e. Replicate analysis of these reference materials showed good accuracy. Recoveries from CRMs were higher than $95 \%$ in all the case.

\subsubsection{Water quality index}

With physicochemical and bacteriological determinations in water samples, a water quality index (WQI) was calculated according to Pesce and Wunderlin (2000); which included the parameters normalization and the application of a weighting factor according to the importance of each measured parameter on the water quality. Obtained WQI gives then a non-dimensional number being 100 and 0 the best and worst water quality, respectively.

\subsubsection{Assessment of potential ecological risk associated with sediments}

Sediments are well known to be reservoirs for metals. Therefore, 


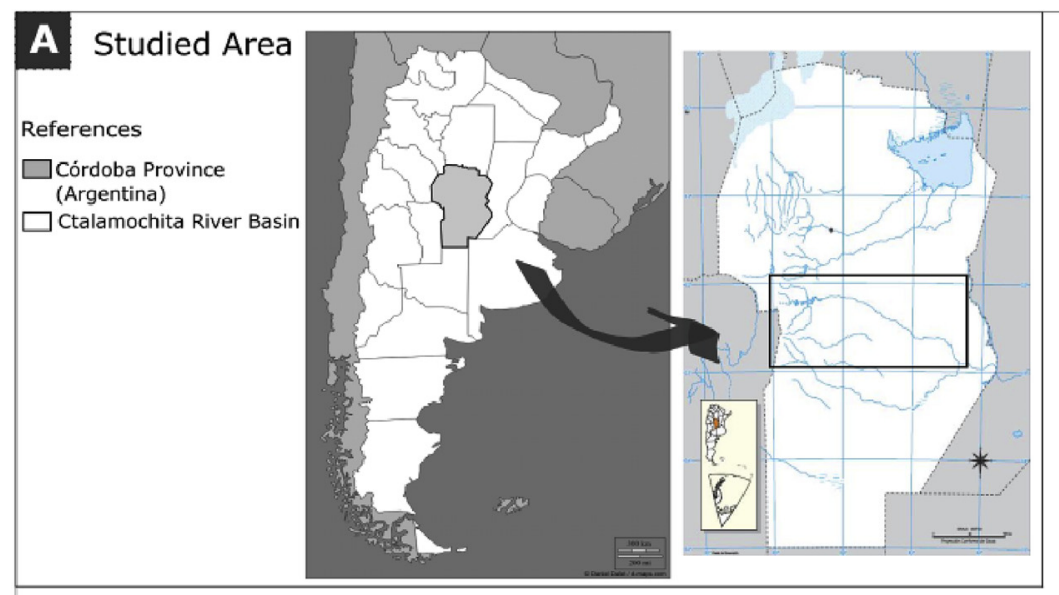

References

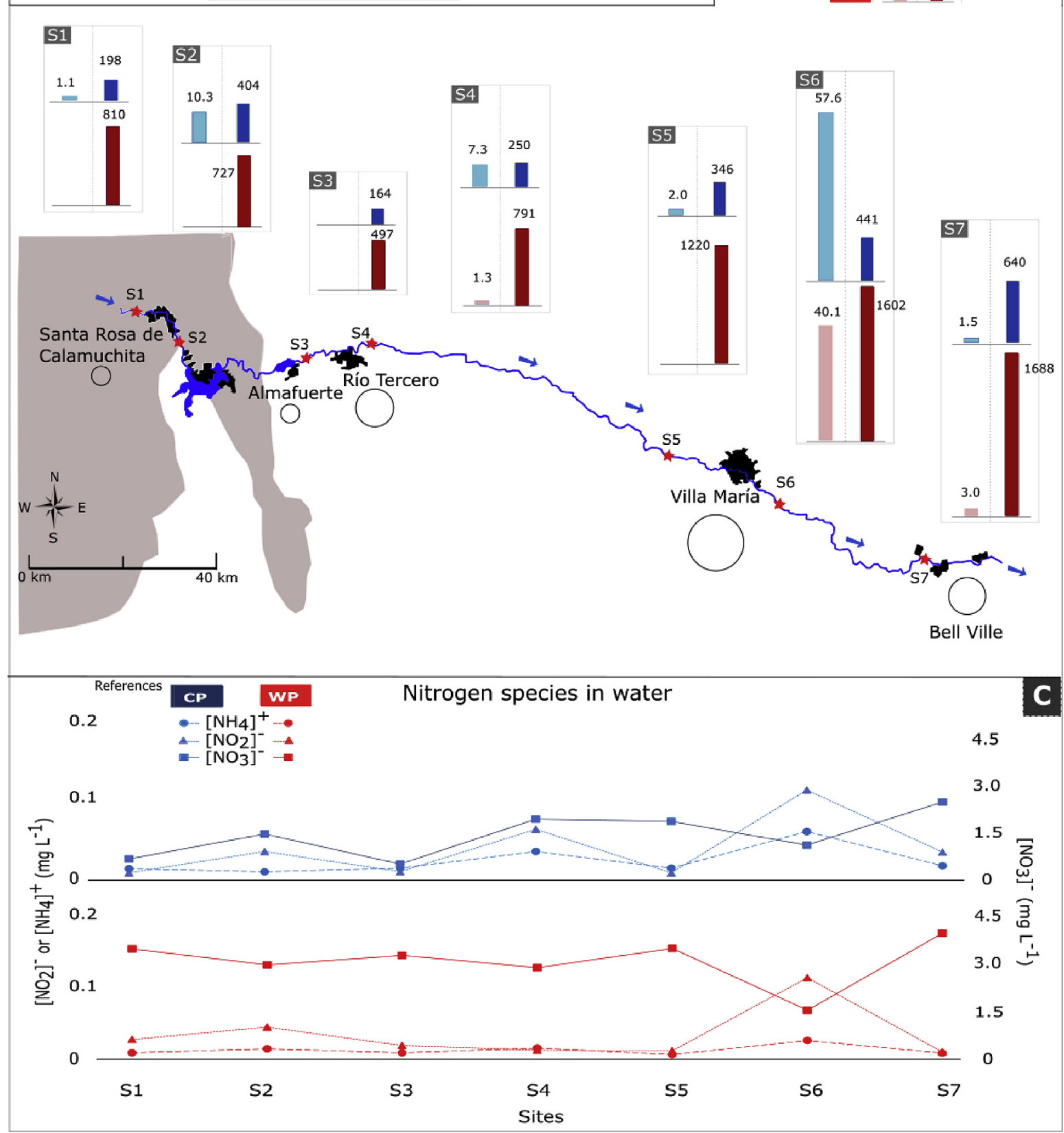

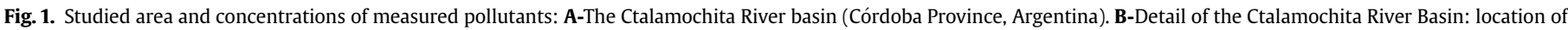

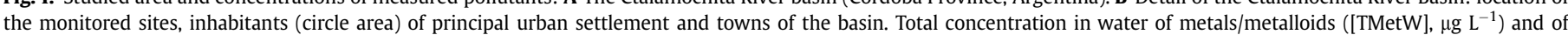

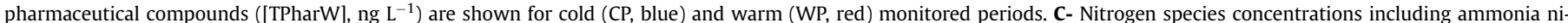

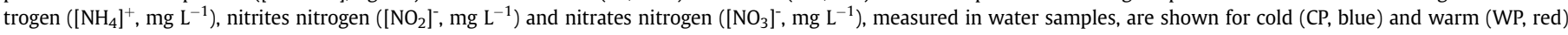
monitored periods. (For interpretation of the references to colour in this figure legend, the reader is referred to the Web version of this article.) 
the potential ecological risk index (RI) and the mean probable effect concentration quotient (MPEC-Q) were calculated to assess the pollution degree and biological effect of multiple heavy metal presence in Ctalamochita River sediments. The RI was calculated according to Hakanson (1980), which is based on eight parameters (polychlorinated biphenyls (PCB), $\mathrm{Hg}, \mathrm{Cd}, \mathrm{As}, \mathrm{Pb}, \mathrm{Cu}, \mathrm{Cr}$ and $\mathrm{Zn}$ ). In the present study, PCB concentrations were excluded. Therefore, RI is calculated as the sum of all risk factors for total metals measured in sediment (A1 + A2 + Ps) during this study as indicated in SM, Formula SM1, SM2, and SM3. According to the obtained values, the potential ecological risk could be classified between different levels as explained below (3.1.4.2).

\subsubsection{Enrichment factor and geo-accumulation index}

The enrichment factor (EF) is useful to indicate the dynamics of an inorganic pollutant or chemical element of the earth's crust that can be transported by natural or anthropogenic process. It was calculated following Ghrefat et al. (2011) with the aim to assess the level of contamination and the possible anthropogenic impact in the sediments. In our study, Fe has been used as a conservative tracer to differentiate natural from anthropogenic components (used formula shown in SM, Formula SM4).

Besides, possible sediment enrichment of metals in aquatic sediments was evaluated in terms of the geoaccumulation index (Igeo) described by Müller (1979) (used formula is shown in SM, Formula SM5).

\subsection{Biomarkers}

Exposed organisms were dissected in leaf, stem and root for the later biomarker determination in each plant section.

\subsubsection{Metals and metalloids accumulation}

For metals and metalloids, accumulation samples were dried up to constant weight at $38^{\circ} \mathrm{C}$. Digestions were carried out according to Bertrand et al. (2016). Briefly, tissues (aprox. $0.02 \mathrm{~g} \mathrm{dw}$ ) were ground and homogenized with mortar, digested with $8 \mathrm{~mL}$ of aqua regia $\left(\mathrm{HNO}_{3}: \mathrm{HCl} ; 1: 3\right)$ and heated at $160^{\circ} \mathrm{C}$ overnight in Teflon tubes. Obtained samples were filtered with $0.45 \mu \mathrm{m}$ nitrocellulose membrane filter and studied elements were measured in plant extracts as described in 2.4.4. Quality assurance and quality control were performed using a certified reference material (peach leaves, NIST1547). The percentages of recovery from tissues were $102 \pm 16 \%$. Results were reported in $\mu \mathrm{g} \mathrm{g}^{-1}$ dry weight $(\mathrm{dw})$.

\subsubsection{Pigment content}

Chlorophyll (Chl) and pheophytins (Pheo) concentrations were determined in leaf and stem of $P$. pusillus according to Wintermans and de Mots (1965). Concentrations of pigments in plant extracts were measured in triplicate by visible spectrophotometry using a microplate reader (Bio-Tek, Synergy HT; $\mathrm{Chl}=649$ and $665 \mathrm{~nm}$; Pheo $=654$ and $666 \mathrm{~nm}$, after hydrochloric acid addition). Concentrations were calculated and reported in $\mu \mathrm{g} \mathrm{g}^{-1}$ wet weight $(w w)$.

\subsubsection{Enzyme activity}

Enzyme extracts of $P$. pusillus were prepared according to Bertrand et al. (2017). After removal of cell debris (10 min at $13,000 \mathrm{~g}, 4^{\circ} \mathrm{C}$ ), the membrane fraction of the extracts were separated by centrifugation at $105,000 \mathrm{~g}$ for $60 \mathrm{~min}$. The remaining supernatant, defined as the soluble (cytosolic) fraction was used for enzyme measurement. Enzymatic activities were determined in triplicated by spectrophotometry, using a microplate reader (BioTek, Synergy HT). The activity of glutathione peroxidase (GPx; EC 1.11.1.9) was determined as reported by Drotar et al. (1985) using hydrogen peroxide $\left(\mathrm{H}_{2} \mathrm{O}_{2}\right)$ as substrate. The guaiacol peroxidase (POD) activity was measured using guaiacol and $\mathrm{H}_{2} \mathrm{O}_{2}$ as substrates (Bergmeyer, 1983). Superoxide dismutase activity was determined by using the photochemical $p$-nitroblue tetrazolium chloride (NBT) reduction method as described by Aiassa et al. (2010) (SOD; EC 1.15.1.1). The activity of all enzymes assessed was calculated in terms of the protein content of the sample extract (Bradford, 1976) and is reported in nanokatals per milligram of protein (nkat mg prot $^{-1}$ ), where 1 nkat is the conversion of $1 \mathrm{nmol}$ of substrate per second. Likewise, one unit of SOD activity is defined as the amount of enzyme required to cause $50 \%$ inhibition in the reduction of NBT. The protein quantification was performed using bovine serum albumin as standard.

\subsubsection{Integrated biomarker response}

One general stress index, the integrated biomarker response (IBR), was calculated as it was described in Bertrand et al. (2018) following the methods proposed by Beliaeff and Burgeot (2002). A higher value of IBR means a greater response expressed by the exposed organisms.

\subsection{Data analysis}

\subsubsection{Statistical treatment}

Generalized Linear Mixed Models were fitted for biomarkers responses for each studied period, including all macrophyte sectors when indicated, using Infostat Software (Di Rienzo et al., 2017). Then, normality and variance homogeneity were tested, being a variance function applied if necessary. A posteriori test LSD Fisher, with Bonferroni errors' correction when necessary, was used to determine significant differences between the means $(\mathrm{p}<0.05)$. Correlations and Kruskal Wallis analysis were carried out with mentioned software. Discriminant analysis (DA) was performed with Statistic Software 8.0 with the aim to select those biomarkers with higher contribution to the discrimination between groups (monitored sites). Finally, principal component analysis (PCA) was carried out using "factoextra" $\mathrm{R}$ package of $\mathrm{R}$ Studio Software (Version 1.1.153) to investigate the associations between the macrophyte stress levels and the environmental variables in the studied sites.

With the aim to evaluate which pollutants explained best the distribution of the dependent variable (stress levels expressed as IBR), multiple linear regression models (MLRM) were fitted with $R$ Studio software using "car" and "Rcpp" packages. The collinearity was tested with the "vif" function and variables with high values $(>10)$ were ruled out in each built model. The best model was selected using a "both" function where the independent variables (Xs) selection combine forward and backward methods leaving those Xs that explain best the distribution of the dependent variable (Y). Those variables with values below the limit of detection in all sites were not considered. Pharmaceutical compounds could not be included in MLRM due to the low individual frequency of quantification in monitored sites. Therefore, four models were fitted for metals and metalloids concentrations in water and in the bioavailable fraction of sediments during $\mathrm{CP}$ and WP. For this statistical analysis, a value of $\mathrm{LOD} / 2$ was considered for all values below the LOD.

\section{Results and discussion}

\subsection{Environmental scenario of the Ctalamochita River basin}

\subsubsection{Physicochemical characteristics}

The quality of freshwaters has been identified as a conditioning factor of resources uses as well as for biota protection and survival. 
A spatio-temporal variation in water quality index (WQI, Table 1) could be observed along the basin, with lower values measured during the WP when compared to the CP. In general, a decrease in water quality could be observed mostly in those sites downstream cities (S2, S4, S6), being S6 the site with the lowest WQI in both monitored periods. As expected, high concentrations of nitrogen species including ammonia $\left(\left[\mathrm{NH}_{4}\right]^{+}\right)$, nitrites $\left(\left[\mathrm{NO}_{2}\right]^{-}\right)$and nitrates $\left(\left[\mathrm{NO}_{3}\right]^{-}\right)$were found in the same sites (S2, S4, and S6, Fig. 1, Table SM2). Ammonia concentrations are an indication of organic contamination, coming from domestic sewage, industrial waste and fertiliser run-off, among other sources. High nitrate concentrations are associated with diffuse rather than point sources (Pasquini et al., 2011). The higher levels of $\left[\mathrm{NH}_{4}\right]^{+}$and $\left[\mathrm{NO}_{2}\right]^{-}$in S6 could be explained by the proximity of this site to Villa María city sewage discharge $(<3.5 \mathrm{~km})$ indicating that nitrogen species were not yet oxidized. The WQI value in S6 during WP (49\%) indicates an inadequate condition for healthy aquatic life, mainly due to low dissolved oxygen concentration $\left(0.3 \mathrm{mg} \mathrm{L}^{-1}\right)$, increased concentration of $\mathrm{NH}_{4}^{+}\left(0.027 \mathrm{mg} \mathrm{L}^{-1}\right)$ and TCB values (3150000 MPN per $100 \mathrm{~mL}$ ) (SM, Table SM2). Our results evidence the occurrence of water pollution due to inadequately, or not, sewage treatment and, probably, industrial wastewaters discharges.

As for the sediments, no significant differences, in $\mathrm{pH}$ and organic matter (OM) content, between studied period were observed along the basin (CP: $6.5 \pm 0.4 \mathrm{pH}, 9.6 \pm 2.8 \% \mathrm{OM}$; WP: $6.8 \pm 0.4,8.9 \pm 2.7 \% \mathrm{OM})$. Finally, granulometric fractions in samples were: sands $>$ limes and clays $>$ gravel during CP and WP.

\subsubsection{Pharmaceutical compounds in water}

Few studies describe the contamination of water with pharmaceuticals in Argentina (Elorriaga et al., 2013; Ondarza et al., 2019; Valdés et al., 2014). Moreover, the bioaccumulation of pharmaceuticals and their effects on native biota, have been barely reported for Argentina and South America (Maranho and Pereira, 2017; Ondarza et al., 2019; Valdés et al., 2016). Therefore, the ability of native species including macrophyte to bioindicate this kind of contamination has been poorly assessed.

In the present study four out of thirteen studied compounds were quantified: ATE, CBZ, and ENAL in both periods and CLAR in CP (Table 1). Fig. 1 shows temporal differences in [TPharW], with higher concentrations in CP respect to WP. Lower levels of pollutants due to the greater rainfall occurred during the WP $(120 \pm 30 \mathrm{~mm}$ monthly accumulated) when compared to $\mathrm{CP}$ (3.6 $\pm 3.8 \mathrm{~mm}$ monthly accumulated). Unsurprisingly, the highest concentrations of [TPharW] were measured downstream the main cities (S2, S4 and S6, Fig. 1 and Table 1) while no pharmaceuticals were detected at S3, as well as S1, S5 and S7 showed the lowest values. The occurrence of pharmaceutical compounds was in accordance with previously described nitrogen species changes, supporting the anthropic origin of pollutants, mainly through discharges of urban wastewater with low or null treatment.

Within the quantified compounds, ATE and CBZ were those with highest concentrations ( $35 \pm 10 \mathrm{ng} \mathrm{L}^{-1}$ and $20 \pm 2 \mathrm{ng} \mathrm{L}^{-1}$, respectively). Both compounds are characterized by a low removal rate in sewage treatment processes and have been proposed as indicators of urban pollution in previous studies (Clara et al., 2004; Cleuvers, 2005; Miège et al., 2009). Quantified concentrations of ATE, ENAL $\left(2.1 \pm 0.3 \mathrm{ng} \mathrm{L}^{-1}\right)$ and $\mathrm{CBZ}$ were within the reported range for others regions of the world. In freshwater rivers, Gavrilescu et al. (2015) mentioned concentrations of CBZ ranging from 9 to $157 \mathrm{ng} \mathrm{L}^{-1}$ in Europe, from 25 to $34.7 \mathrm{ng} \mathrm{L}^{-1}$ in countries from Asia and Australian region and from 2.7 to $113.7 \mathrm{ng} \mathrm{L}^{-1}$ in North America. The same authors informed concentrations of ATE ( $\left.314 \mathrm{ng} \mathrm{L}^{-1}\right)$ for European region whereas others authors reported concentrations from 5.8 to $1437 \mathrm{ng} \mathrm{L}^{-1}$ in South American countries including Brazil and
Argentina (de Sousa et al., 2014; Quadra et al., 2017; Valdés et al., 2014). However, the only former report of pharmaceutical compounds in Ctalamochita River basin accounts for the presence of CBZ and ATE (Elorriaga et al., 2013). Therefore, the present study is the first report of ENAL and CLAR for this basin.

Pharmaceutical guidelines for aquatic biota protection have not been established at the time of the present study. Nonetheless, negative effects on animal and macrophyte, due to the presence of this kind of pollutants in aquatic environment have been described by Valdés et al. (2016) and Brain et al. (2004), among others. Therefore, the negative impact of domestic sewage on the water quality will probably condition the water uses and aquatic biota health status.

\subsubsection{Metals and metalloids in water and sediments}

3.1.3.1. Water. Studied basin evidenced spatiotemporal variability in the total concentrations of metals and metalloids in water ([TMetW], Fig. 1). Lower values were observed in the site located immediately downstream a chain of reservoirs (S3), during both periods, which probably favoured the sedimentation of particles and metals as well as the occurrence of thermal stratification especially during the cold period (Wetzel, 2001; Yi et al., 2011). The intense rainfalls occurred during WP, could explain the higher [TMetW] quantified during this period, compared to CP. Rainfalls would have favoured the surface runoff from riversides and surrounding lands increasing the suspended materials and soluble metals in water.

Some elements ( $\mathrm{Pb}, \mathrm{Al}, \mathrm{As}, \mathrm{B}, \mathrm{Hg}$; Table 1) were quantified in concentrations higher than that suggested mainly for the protection of aquatic biota in freshwaters, but also for water resources used as drinking water source as well as crop irrigation (AEWQG, 2003; USEPA, 1988).

3.1.3.2. Sediments. Sediments in aquatic ecosystems were described as metals deposit from where the elements could be remobilised to the water column depending on hydrodynamics, biogeochemical processes and environmental conditions (Luoma and Rainbow, 2008).

Concentrations of more environmentally relevant elements were compared with sediments quality guidelines (MacDonald et al., 2000; SM Table SM3 and Figure SM3). Results point out the total $\mathrm{Hg}$ concentration $(\mathrm{A} 1+\mathrm{A} 2+\mathrm{Ps})$ as the unique metal surpassing, at five sites including $\mathrm{S} 1$, the concentration above which adverse effects are expected to be frequent (1.06 $\mathrm{mg} \mathrm{kg}^{-1} \mathrm{dw}$ ) during the $\mathrm{CP}$. For the WP, concentrations of $\mathrm{Hg}$ in sediments diminished and probable effect concentration (PEC) value was not surpassed. The worrisome $\mathrm{Hg}$ concentrations in the Ctalamochita Basin have already been described in a previous study, at least for one season (Bertrand et al., 2018). Mercury sources include industrial activities and pesticides use but also a significant natural contribution such as volcanoes emissions and the presence of volcanic sediments. Therefore, significant concentrations of $\mathrm{Hg}$ in sites with low anthropic activities, like S1, could be explained by atmospheric transport and its later deposition in addition to the natural background.

Elements concentrations in sediments will depend on rocks and parent materials levels, pedological processes but also anthropogenic activities. Pearson correlations among metals in sediments evidenced the existence of close and significant positive correlations among $\mathrm{Ag}, \mathrm{Cd}, \mathrm{Cr}, \mathrm{Cu}, \mathrm{Hg}, \mathrm{Pb}$ and $\mathrm{Zn}$ during both periods (SM, Table SM4) which are usually characterized by reaching rivers from common sources including coal burning, industrial activities and an intense use of pesticides (Li et al., 2009; Ruchter and Sures, 2015). On the other hand, Fe could be considered as a reference metal and, in most cases, anthropogenic sources are smaller compared to 
Table 1

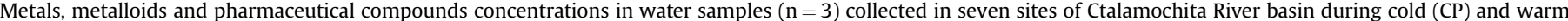

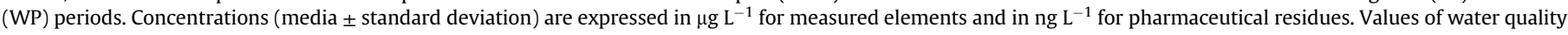
index (WQI) for each monitored site, and studied periods, are shown. Concentrations of metals and metalloids surpassing environmental guideline are indicated in bold.

\begin{tabular}{|c|c|c|c|c|c|c|c|c|c|}
\hline & & Period & $\mathrm{S} 1$ & $\mathrm{~S} 2$ & S3 & S4 & S5 & S6 & S7 \\
\hline \multirow[t]{40}{*}{ Metals and Metalloids } & \multirow[t]{2}{*}{$\mathrm{Ag}$} & $C P$ & $<$ LOD & $<$ LOD & $<$ LOD & $<$ LOD & $0.33 \pm 0.02$ & $<$ LOD & $<$ LOD \\
\hline & & $W P$ & $<$ LOD & $<$ LOD & $<$ LOD & $<$ LOD & $<\mathrm{LOD}^{-}$ & $<$LOD & $<\mathrm{LOD}$ \\
\hline & \multirow[t]{2}{*}{$\mathrm{Al}$} & $C P$ & $56.8 \pm 1.2$ & $44.9 \pm 0.5$ & $<\mathrm{LOD}$ & $27.0 \pm 0.5$ & $84.5 \pm 0.6$ & $112.2 \pm 0.2^{b}$ & $105.3 \pm 0.4^{b}$ \\
\hline & & $W P$ & $131.7 \pm 4.8^{b}$ & $169.9 \pm 3.6^{b}$ & $<$ LOQ & $98.8 \pm 1.4$ & $415.2 \pm 8.5^{b}$ & $578.5 \pm 2.5$ & $465.8 \pm 12.7$ \\
\hline & \multirow[t]{2}{*}{ As } & $C P$ & $0.19 \pm 0.01$ & $0.71 \pm 0.01$ & $1.95 \pm 0.06$ & $1.95 \pm 0.05$ & $2.06 \pm 0.08$ & $3.45 \pm 0.08$ & $13.3 \pm 0.22$ \\
\hline & & $W P$ & $0.64 \pm 0.05$ & $1.19 \pm 0.06$ & $2.39 \pm 0.10$ & $2.27 \pm 0.05$ & $2.76 \pm 0.02$ & $5.46 \pm 0.13$ & $27.18 \pm 0.40$ \\
\hline & \multirow[t]{2}{*}{ B } & $C P$ & $<$ LOD & $84.2 \pm 0.1$ & $47.3 \pm 0.6$ & $51.2 \pm 0.3$ & $48.6 \pm 0.7$ & $60.6 \pm 0.2$ & $186.3 \pm 4.0$ \\
\hline & & $W P$ & $135.2 \pm 9.4^{\mathrm{d}}$ & $147.1 \pm 4.2^{d}$ & $204.5 \pm 14.7^{d}$ & $206.7 \pm 11.9$ & $202.6 \pm 4.7^{d}$ & $193.8 \pm 13.2$ & $353.2 \pm 2.6$ \\
\hline & \multirow[t]{2}{*}{$\mathrm{Ba}$} & $C P$ & $11.7 \pm 0.3$ & $27.9 \pm 0.5$ & $10.4 \pm 0.1$ & $13.9 \pm 0.1$ & $17.9 \pm 0.3$ & $18.5 \pm 0.3$ & $24.4 \pm 0.2$ \\
\hline & & $W P$ & $7.1 \pm 0.2$ & $13.7 \pm 0.4$ & $12.7 \pm 0.3$ & $16.5 \pm 0.2$ & $26.0 \pm 0.2$ & $32.3 \pm 0.6$ & $32.8 \pm 0.8$ \\
\hline & \multirow[t]{2}{*}{$\mathrm{Cd}$} & $C P$ & $<\mathrm{LOQ}$ & $<\mathrm{LOD}$ & $<\mathrm{LOD}$ & $<\mathrm{LOD}$ & $<\mathrm{LOQ}$ & $<$ LOQ & $<\mathrm{LOQ}$ \\
\hline & & $W P$ & $<$ LOD & $<$ LOD & $<$ LOD & $<$ LOD & $<$ LOD & $<\mathrm{LOD}$ & $<\mathrm{LOD}$ \\
\hline & \multirow[t]{2}{*}{ Co } & $C P$ & $0.10 \pm 0.01$ & $0.09 \pm 0.01$ & $0.02 \pm 0.01$ & $0.04 \pm 0.01$ & $0.07 \pm 0.01$ & $0.11 \pm 0.01$ & $0.15 \pm 0.01$ \\
\hline & & $W P$ & $0.19 \pm 0.03$ & $0.17 \pm 0.02$ & $0.06 \pm 0.01$ & $0.11 \pm 0.01$ & $0.29 \pm 0.01$ & $0.42 \pm 0.02$ & $0.33 \pm 0.02$ \\
\hline & \multirow[t]{2}{*}{$\mathrm{Cr}$} & $C P$ & $<\mathrm{LOD}$ & $<\mathrm{LQ}$ & $<$ LOD & $1.45 \pm 0.03$ & $0.53 \pm 0.01$ & $0.64 \pm 0.01$ & $0.34 \pm 0.01$ \\
\hline & & $W P$ & $1.14 \pm 0.03$ & $0.31 \pm 0.01$ & $<\mathrm{LOQ}$ & $1.05 \pm 0.02$ & $1.30 \pm 0.03$ & $1.49 \pm 0.01$ & $1.00 \pm 0.07$ \\
\hline & \multirow[t]{2}{*}{$\mathrm{Cu}$} & $C P$ & $1.97 \pm 0.13$ & $<\mathrm{LOD}$ & $<\mathrm{LOD}$ & $1.22 \pm 0.11$ & $1.39 \pm 0.07$ & $<$ LOD & $0.82 \pm 0.11$ \\
\hline & & $W P$ & $<\mathrm{LOD}^{-}$ & $<$LOD & $<$LOD & $3.44 \pm 0.06$ & $<$ LOD & $<$ LOD & $<$ LOD \\
\hline & \multirow[t]{2}{*}{$\mathrm{Fe}$} & $C P$ & $23.1 \pm 0.2$ & $56.2 \pm 0.8$ & $14.9 \pm 2.2$ & $30.2 \pm 0.2$ & $70.6 \pm 1.2$ & $106.1 \pm 0.5$ & $100.1 \pm 0.5$ \\
\hline & & $W P$ & $231.9 \pm 7.7$ & $261.3 \pm 5.4$ & $114.7 \pm 1.3$ & $235.7 \pm 4.8$ & $388.1 \pm 6.1$ & $518.3 \pm 6.1$ & $474.9 \pm 13.8$ \\
\hline & \multirow[t]{2}{*}{$\mathrm{Hg}$} & $C P$ & $<\mathrm{LOQ}$ & $<$ LOD & $<\mathrm{LOD}$ & $<$ LOD & $5.55 \pm 0.21$ & $1.03 \pm 0.09$ & $<\mathrm{LOQ}$ \\
\hline & & $W P$ & $<\mathrm{LOD}$ & $<\mathrm{LOD}$ & $<\mathrm{LOD}$ & $<$ LOD & $<\mathrm{LOD}$ & $<\mathrm{LOD}$ & $<\mathrm{LOD}$ \\
\hline & \multirow[t]{2}{*}{ Mn } & $C P$ & $2.64 \pm 0.04$ & $14.29 \pm 0.28$ & $4.14 \pm 0.24$ & $11.09 \pm 0.28$ & $13.09 \pm 0.09$ & $24.19 \pm 0.15$ & $28.35 \pm 0.27$ \\
\hline & & $W P$ & $250.76 \pm 7.70$ & $55.44 \pm 1.14$ & $51.42 \pm 0.75$ & $77.48 \pm 0.49$ & $34.87 \pm 0.80$ & $101.52 \pm 1.44$ & $43.21 \pm 1.18$ \\
\hline & \multirow[t]{2}{*}{ Mo } & $C P$ & $0.33 \pm 0.04$ & $0.90 \pm 0.06$ & $0.91 \pm 0.04$ & $2.27 \pm 0.03$ & $1.91 \pm 0.08$ & $1.42 \pm 0.02$ & $4.22 \pm 0.11$ \\
\hline & & $W P$ & $0.72 \pm 0.09$ & $0.70 \pm 0.08$ & $1.69 \pm 0.12$ & $2.42 \pm 0.07$ & $2.61 \pm 0.12$ & $1.91 \pm 0.10$ & $6.91 \pm 0.13$ \\
\hline & \multirow[t]{2}{*}{$\mathrm{Ni}$} & $C P$ & $0.23 \pm 0.04$ & $<$ LOD & $<\mathrm{LOQ}$ & $0.39 \pm 0.01$ & $0.40 \pm 0.01$ & $0.42 \pm 0.01$ & $0.34 \pm 0.02$ \\
\hline & & $W P$ & $0.43 \pm 0.09$ & $<\mathrm{LOD}$ & $<\mathrm{LOD}$ & $<\mathrm{LOD}$ & $<$ LOD & $<$ LOD & $<\mathrm{LOD}$ \\
\hline & \multirow[t]{2}{*}{$\mathrm{Pb}$} & $C P$ & $6.91 \pm 0.19^{a}$ & $1.01 \pm 0.04$ & $0.45 \pm 0.01$ & $0.47 \pm 0.01$ & $0.57 \pm 0.01$ & $0.54 \pm 0.01$ & $0.82 \pm 0.02$ \\
\hline & & $W P$ & $0.09 \pm 0.01$ & $0.08 \pm 0.03$ & $0.79 \pm 0.03$ & $3.90 \pm 0.08$ & $1.47 \pm 0.05$ & $1.44 \pm 0.05$ & $1.01 \pm 0.05$ \\
\hline & \multirow[t]{2}{*}{$\mathrm{Rb}$} & $C P$ & $0.68 \pm 0.02$ & $0.69 \pm 0.03$ & $1.03 \pm 0.03$ & $1.21 \pm 0.02$ & $1.11 \pm 0.03$ & $1.53 \pm 0.05$ & $1.53 \pm 0.09$ \\
\hline & & $W P$ & $0.95 \pm 0.01$ & $1.10 \pm 0.02$ & $1.20 \pm 0.02$ & $1.37 \pm 0.09$ & $2.18 \pm 0.06$ & $3.29 \pm 0.03$ & $3.73 \pm 0.09$ \\
\hline & \multirow[t]{2}{*}{ Se } & $C P$ & $<\mathrm{LOD}$ & $<$ LOD & $<$ LOD & $<$ LOD & $<$ LOD & $<$ LOD & $<$ LOD \\
\hline & & $W P$ & $<\mathrm{LOD}$ & $<$ LOD & $<$ LOD & $<$ LOD & $<$ LOD & $<\mathrm{LOD}$ & $<$ LOD \\
\hline & \multirow[t]{2}{*}{$\mathrm{Sr}$} & $C P$ & $63.51 \pm 0.34$ & $160.70 \pm 0.20$ & $74.73 \pm 0.35$ & $86.19 \pm 1.76$ & $82.87 \pm 0.49$ & $96.41 \pm 0.45$ & $146.22 \pm 2.75$ \\
\hline & & $W P$ & $34.98 \pm 0.51$ & $66.73 \pm 0.54$ & $100.96 \pm 1.04$ & $110.67 \pm 2.08$ & $124.35 \pm 1.48$ & $132.52 \pm 1.08$ & $222.83 \pm 1.59$ \\
\hline & V & $C P$ & $1.22 \pm 0.03$ & $3.36 \pm 0.02$ & $2.36 \pm 0.04$ & $2.34 \pm 0.03$ & $3.28 \pm 0.04$ & $6.34 \pm 0.01$ & $19.4 \pm 0.11$ \\
\hline & & $W P$ & $1.77 \pm 0.07$ & $3.39 \pm 0.09$ & $2.87 \pm 0.02$ & $3.69 \pm 0.04$ & $6.21 \pm 0.14$ & $11.92 \pm 0.16$ & $44.18 \pm 1.23$ \\
\hline & $\mathrm{Zn}$ & $C P$ & $29.83 \pm 0.96$ & $8.33 \pm 0.29$ & $5.34 \pm 0.19$ & $18.93 \pm 0.29$ & $10.72 \pm 0.59$ & $7.09 \pm 0.19$ & $8.07 \pm 0.35$ \\
\hline & & $W P$ & $12.01 \pm 0.66$ & $5.45 \pm 0.75$ & $4.04 \pm 0.19$ & $26.83 \pm 0.76$ & $11.93 \pm 0.13$ & $19.41 \pm 0.07$ & $10.55 \pm 0.89$ \\
\hline PharmaceuticalCompounds & ATE & $C P$ & $<$ LOD & $2.3 \pm 0.6$ & $<$ LOD & $7.3 \pm 0.2$ & $<$ LOD & $36 \pm 2$ & $<\mathrm{LOQ}$ \\
\hline & & $W P$ & $<$ LOD & $<\mathrm{LOD}$ & $<$ LOD & $1.29 \pm 0.01$ & $<$ LOD & $35 \pm 10$ & $<$ LOD \\
\hline & $\mathrm{CBZ}$ & $C P$ & $1.1 \pm 0.1$ & $<$ LOD & $<$ LOD & $<$ LOD & $2.0 \pm 0.4$ & $20 \pm 2$ & $1.54 \pm 0.01$ \\
\hline & & $W P$ & $<$ LOD & $<$ LOD & $<$ LOD & $<$ LOD & $<$ LOQ & $3 \pm 1$ & $3 \pm 1$ \\
\hline & CLAR & $C P$ & $<$ LOD & $8.0 \pm 1.0$ & $<$ LOD & $<$ LOD & $<$ LOD & $<\mathrm{LOD}$ & $<\mathrm{LOD}$ \\
\hline & & $W P$ & $<$ LOD & $<\mathrm{LOD}$ & $<$ LOD & $<$ LOD & $<$ LOD & $<$ LOD & $<$ LOD \\
\hline & ENAL & $C P$ & $<\mathrm{LOD}$ & $<$ LOD & $<\mathrm{LOD}$ & $<$ LOD & $<$ LOD & $1.6 \pm 0.3$ & $<$ LOD \\
\hline & & $W P$ & $<$ LOD & $<$ LOD & $<$ LOD & $<$ LOD & $<$ LOD & $2.1 \pm 0.3$ & $<$ LOD \\
\hline & WQI & $C P$ & 87 & 81 & 80 & 82 & 82 & 72 & 76 \\
\hline & & $W P$ & 85 & 74 & 79 & 71 & 76 & 49 & 73 \\
\hline
\end{tabular}

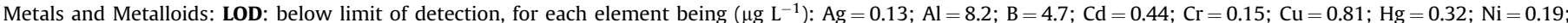
$\mathrm{Se}=1.6 . \mathbf{L O Q}$ : below limit of quantification, for each element being $\left(\mu \mathrm{L}^{-1}\right)$ : $\mathrm{Al}=19.40 ; \mathrm{Cd}=0.48 ; \mathrm{Cr}=0.38 ; \mathrm{Hg}=0.85 ; \mathrm{Ni}=0.22$.

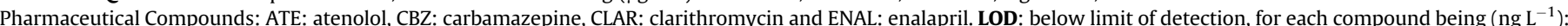

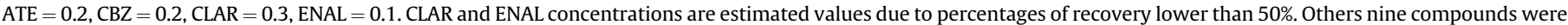

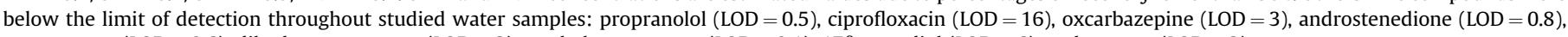
testosterone $(\mathrm{LOD}=0.6)$, dihydrotestosterone $(\mathrm{LOD}=2)$, methyltestosterone $(\mathrm{LOD}=0.1)$, $17 \beta$-estradiol $(\mathrm{LOD}=6)$, and estrone $(\mathrm{LOD}=2)$.

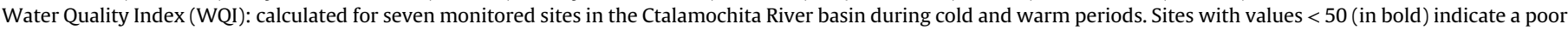
water quality and inadequate condition for aquatic life.

a Concentrations higher than recommended for the protection of aquatic biota in freshwaters by the Argentinean Environmental Water Quality Guidelines (AEWQG, 2003): $\mathrm{Pb}<1.59 \mu \mathrm{g} \mathrm{L}^{-1} ; \mathrm{As} \leq 15 \mu \mathrm{g} \mathrm{L}^{-1} ; \mathrm{Hg} \leq 0.029 \mu \mathrm{g} \mathrm{L}^{-1}, \mathrm{Ag} \leq 0.028 \mu \mathrm{g} \mathrm{L}^{-1}$.

b Concentrations higher than recommended for the protection of aquatic biota in freshwaters by the United States Environmental Protection Agency (USEPA, 1988): $\mathrm{Al}<89 \mu \mathrm{g} \mathrm{L}^{-1}$ for chronic exposure.

c Concentrations higher than recommended for water resources used to purification and human consumption by the Argentinean Environmental Water Quality Guidelines (AEWOG, 2003): $\mathrm{Hg} \leq 4 \mu \mathrm{g} \mathrm{L}^{-1}$.

d Concentrations higher than recommended for water resources used to crop irrigation by the Argentinean Environmental Water Quality Guidelines (AEWQG, 2003): $\mathrm{B} \leq 100 \mu \mathrm{g} \mathrm{L}^{-1}$. 
naturally present levels. In the present study, $\mathrm{Al}, \mathrm{Rb}, \mathrm{Co}, \mathrm{Ni}$ showed a positive and significant correlation with Fe in CP and WP (SM, Table SM4) probably indicating a natural source of these metals.

A geoaccumulation index (Igeo) and an enrichment factor (EF) were calculated to assess the possible anthropogenic impact in sediments of the studied river (Ghrefat et al., 2011). According to the Igeo results, surface sediments were not contaminated with $\mathrm{Cr}$, $\mathrm{Cu}, \mathrm{Cd}, \mathrm{Pb}, \mathrm{Zn}$, and $\mathrm{As}($ Igeo $<0)$ in both monitored periods. On the contrary, a moderate contamination for $\mathrm{Ag}(1<$ Igeo $<2)$ and a strong contamination for $\mathrm{Hg}(3<$ Igeo $<4)$ occurred in the $\mathrm{CP}$, whereas Igeo decayed in the WP for both metals, reaching moderate or uncontaminated levels.

The EF results showed a different pattern and decreased according to the following order $\mathrm{Hg}>\mathrm{Ag}>\mathrm{Cd}>\mathrm{Pb}>\mathrm{Zn}>\mathrm{Cu}>\mathrm{Cr}$ for the $\mathrm{CP}$ and $\mathrm{Ag}>\mathrm{Hg}>\mathrm{Pb}>\mathrm{Zn}>\mathrm{Cu}>\mathrm{Cr}>\mathrm{Cd}$ for the WP. Mercury showed from moderately severe $(E F=5-10, S 2$ and $S 4)$ to extremely severe $(E F>50$, all others monitored sites) enrichment in the $C P$, and a severe $(E F=10-25$, S5 and $S 6)$ or very severe $(E F=25-50, S 4)$ enrichment in the WP (data not shown). Silver presented similar EF in both periods, varying between minor enrichment $(E F=1-3)$ to very severe enrichment $(E F=25-50)$, especially in sites located in the lower basin (from S4 to S6 in both periods, as well as S1 and S7 in CP). Cadmium showed EF between minor enrichment (2.9) and severe enrichment (10.3) in CP, whereas no enrichment $(\mathrm{EF}<1)$ was detected in WP for all the studied sites. Lead showed $\mathrm{EF}$ values included between moderate $(E F=3-5)$ and moderately severe $(E F=5-10)$ enrichment in both periods. Finally, Zinc varied between a minor and moderately severe enrichment being S4 that with maximal value (9.9) in the basin. Therefore, according to $\mathrm{EF}$, the metal contamination of basin sediments due to anthropogenic activities ( $\mathrm{EF}>1)$ is mainly associated with $\mathrm{Hg}, \mathrm{Ag}, \mathrm{Pb}, \mathrm{Cd}$, and $\mathrm{Zn}$ levels. Consequently, these results show the usefulness of different approaches in enrichment assessment since the interpretation could vary.

\subsubsection{Risk assessment of metals and metalloids in sediments}

3.1.4.1. Metals and metalloids in bioavailable fractions. The potential mobility and bioavailability of metals and metalloids in sediments determine their toxicity for organisms. Therefore, considering only the total level of elements probably, can not accurately reflect its risk in the environment. For the Ctalamochita River, the obtained results showed a significant variation in $\mathrm{A} 1+\mathrm{A} 2$ fraction (bioavailable) among elements. During the $\mathrm{CP}$, the bioavailable fraction of $\mathrm{Cr}, \mathrm{Hg}$ and As represented lower than $10 \%$ of the total quantified concentration (SM, Table SM3). In a different way, for Cd, $\mathrm{Cu}, \mathrm{Zn}$ and $\mathrm{Pb}$, the bioavailable fraction reached up to $36 \%$ of total metal. Conversely, in the WP the observed pattern was similar only for As (bioavailable fraction $<10 \%$ ). For the other metals, A1 + A2 increased, varying from $20 \%$ to $70 \%$, according to the following order: $\mathrm{Pb}<\mathrm{Cu}<\mathrm{Cd}<\mathrm{Zn}<\mathrm{Cr}<\mathrm{Hg}$. In $\mathrm{S} 1$ and $\mathrm{S} 2, \mathrm{Hg}$ showed exceptional high proportion bioavailable compared with other sites. Those results evidence that despite significant higher total concentrations of $\mathrm{Hg}$ in sediments during the CP $(4.16 \pm 3.89 \mathrm{mg}$ $\left.\mathrm{kg}^{-1} \mathrm{dw}\right)$ when compared to WP $\left(0.37 \pm 0.32 \mathrm{mg} \mathrm{kg}^{-1} \mathrm{dw}\right)$, the bioavailability reaches the highest percentages in WP, probably due to the variation in water temperature and oxygen levels in sediments (Yang et al., 2014).

3.1.4.2. Risk index of metals. In order to evaluate the combined pollution risk in sediments associated with the presence of $\mathrm{As}, \mathrm{Cd}$, $\mathrm{Cr}, \mathrm{Cu}, \mathrm{Hg}, \mathrm{Pb}, \mathrm{Zn}$, the potential ecological risk index (RI) and the mean probable effect concentration quotient (mPEC-Q) were calculated for Ctalamochita River basin. Fig. 2 shows that in the $\mathrm{CP}$, a "very high" risk index was observed in S1, S5, S6 and S7, while in S3 the risk index was "considerable". The others sites presented a "low" risk index. Those metals that contributed most to the RI values (monomial potential ecological risk factor, $\mathrm{E}_{\mathrm{r}}^{\mathrm{i}}$ ) were $\mathrm{Hg}$ and, to a lesser extent, $\mathrm{Cd}$ (data not shown). In particular, for $\mathrm{Hg}$, moderate values of $\mathrm{E}_{\mathrm{r}}^{\mathrm{i}}$ were calculated in $\mathrm{S} 2$ and $\mathrm{S} 4\left(40 \leq \mathrm{E}_{\mathrm{r}}^{\mathrm{i}} \leq 80\right)$, while obtained $E_{r}^{i}$ were very high in all the others sites $\left(E_{r}^{i} \geq 320\right)$. On the other hand, in the WP, the RI decreased in most of the sites compared with CP. However, S4 showed a "considerable" RI due to a moderate $\mathrm{E}_{\mathrm{r}}^{\mathrm{i}}$ associated with $\mathrm{Hg}$. In a similar way, S5 and S6 presented also a moderate $\mathrm{E}_{\mathrm{r}}^{\mathrm{i}}$ related to $\mathrm{Hg}$ concentrations, although the RI values were "low". The MPEC-Q in sediment varied from 0.08 to 1.27 with an average value of 0.63 in the $C P$, while for the WP, the mPEC-Q in sediment varied from 0.04 to 0.20 with an average of 0.11 . The S2, for the both studied periods, was classified as the least toxic site, in relation to metals in sediments. Sites from S3 to S7 in $\mathrm{CP}$ and S4, S5, and S6 in WP presented MPEC-Q values between 0.1 and 1 (Fig. 2) indicating an incidence probability of toxicity with a range of 15-29\% (Long et al., 2006). In the agreement, described sites presented a "considerable" (S3) and "high" RI during CP, whereas in WP, the RI was "moderate" in S4 and "low" for the others sites. Similar to RI, the highest value of mPEC-Q in CP was found at site $S 1$ (1.27) indicating that adverse biological effects can potentially occur.
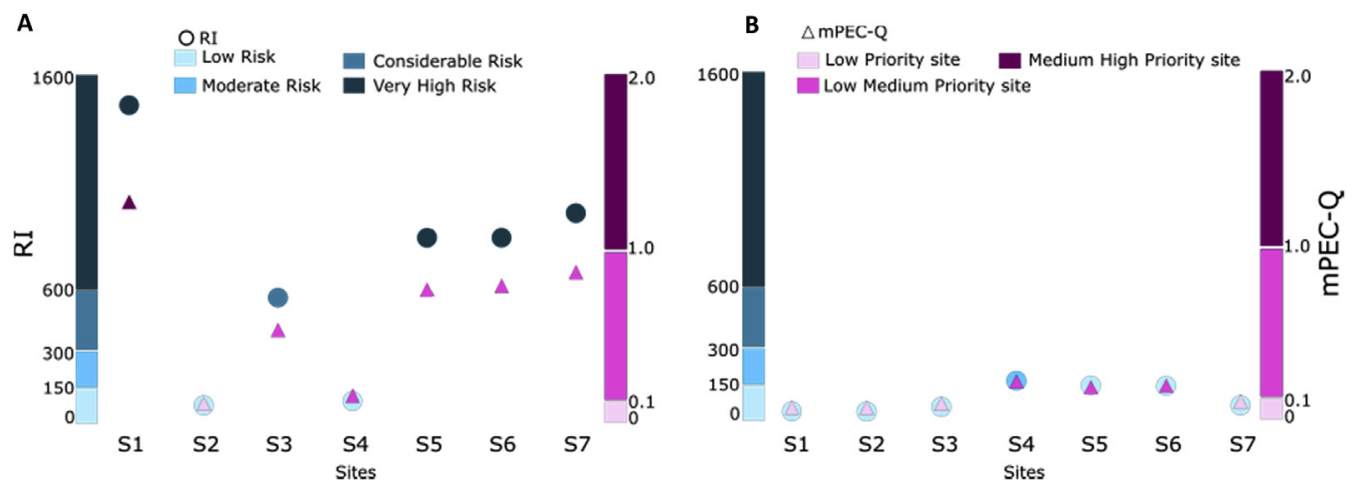

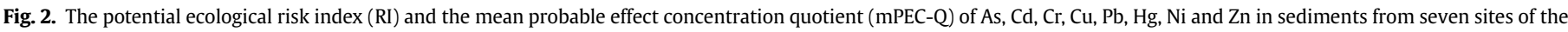

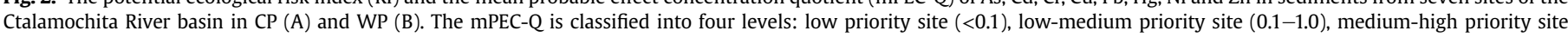

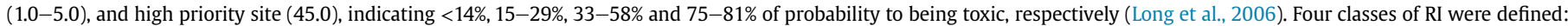
low risk $(\mathrm{RI}<150)$, moderate risk $(150>\mathrm{RI}<300)$, considerable risk $(300>\mathrm{RI}<600)$, and very high risk $(\mathrm{RI}>600)($ Hakanson, 1980$)$. 


\subsection{Biomonitor responses}

\subsubsection{Metals and metalloids accumulation in macrophyte}

Exposed macrophyte showed different patterns of metal accumulation depending on to the plant sector considered (SM, Table SM5). In general, the levels of metals and metalloids in macrophyte sections showed the following order: stem $<$ root $<$ leaf in the $\mathrm{CP}$ and the inverse pattern during WP:leaf $<$ root $<$ stem. During the $\mathrm{CP}$, the maximum accumulation concentrations in leaf and root occurred in S4, thus exceeding 7 and 10 times the accumulation values of the reference site (S1), respectively. On the other hand, maximum accumulation levels in stem were observed in S5, doubling S1. In WP, the maximum concentrations of total accumulation in leaf and root occurred in S3, doubling the values at S1. In contrast, stem showed the highest concentrations of total metals accumulated in S4 and the lowest in S6 (SM, Table SM5). An acute laboratory exposure of P. pusillus to $\mathrm{Zn}$ showed higher metal accumulation in leaf when compared to stem and root, a similar pattern to the observed in the CP (Bertrand et al., 2016). Previously, Duman et al. (2007) have reported a seasonal variation in the accumulation of metals in aquatic macrophytes due to environmental factors but also physiological changes in photosynthetic organisms. Moreover, Duman et al. (2006) reported variations in metal accumulation in Potamogeton lucens depending not only on seasons but also plant sections and elements analysed. In agreement with the pattern described for the WP (summer time) in the present study, Duman et al. (2006) reported for most of the studied metals higher concentrations in root or stem sections than in leaf tissues during de summer season. These results could be indicating an attempt of the plant to protect leaves tissues over the stem or roots. Translocation from leaf to stem, or lower uptake rates in the foliar region compared with stem or roots, could be possible strategies to avoid plant damages. Unfortunately, there is no data available for winter season to be a compared with $P$. pusillus results from CP.

Associations between accumulated elements in the biomonitor and environmental levels were analysed through Pearson correlations (Table 2). In general, the accumulation in leaf and stem showed a significant correlation with metals water concentrations, for both monitored periods. The wider surface of leaves and stems in contact with water could explain the observed correlation for dissolved $\mathrm{Al}, \mathrm{As}, \mathrm{Ba}, \mathrm{Cr}, \mathrm{Pb}, \mathrm{Sr}$, and $\mathrm{V}$ (Table 2). By the contrary, the accumulation of metals in roots was correlated with the metals measured in the bioavailable and Ps fractions of the sediments. Considering P. pusillus is a rooted plant, the high capacity of roots to accumulate metals and metalloids from sediments could be also expected. The results showed significant correlation for $\mathrm{Cd}, \mathrm{Co}, \mathrm{Pb}$, $\mathrm{V}$, and $\mathrm{Zn}$. In particular, the correlation observed for $\mathrm{Al}$ in WP (leaf vs. water) correspond with the quantification of concentrations of this element in levels higher than recommended for the protection of aquatic biota (USEPA, 1988, Table 1). Previously described results would be reflecting the P. pusillus ability to point out, at least in part, metals pollution in aquatic ecosystem and its potential to be used as an active biomonitoring tool. Nevertheless, others elements surpassing environmental guidelines $(\mathrm{Ag}, \mathrm{As}, \mathrm{Hg}, \mathrm{Pb}$ ) seem to not be reflected, at least when metal accumulation is considered. The results obtained in the present study show the complexity of responses in organisms exposed to pollutants mixture being environmental factors (changes in metal concentrations, interactions between metals or with other elements, $\mathrm{pH}$, conductivity, temperature, among others) and plant physiological mechanisms (ex. dilution of metal contents due to growth) the main responsible of variability in the metal uptake (Bonanno et al., 2017; Duman et al., 2006).

\subsubsection{Responses of defence and damage biomarker responses}

3.2.2.1. Pigments. Different patterns of biomarker responses were observed in monitored sites for both periods. In CP, pigments concentrations (Chl-a, Chl-b, Pheo-a, and Pheo-b) decreased significantly or showed a tendency to diminish, in S2, S4, S5, and S6, when compared to the reference site (S1; SM- Figure SM4). Pheo-b also showed a significant decay at S7 in the same period. During the WP the response was less clear, in particular for Chl-a, Chl-b, and Pheo-b. A significant decline was observed at S2 in Chl-a, Chl-b, and Pheo-a. Pheo-a also declined significantly at S4, S5, and S7. On the contrary, the concentrations of Chl-a, Chl-b, Pheo-a, and Pheo-b increased at S6 when compared to the reference site. Also, Pheob increased at S3. Diminution of pigments content, mainly chlorophylls, has been described as an indicator of biomolecule damages under stress conditions in macrophytes tissues, including P. pusillus, when it was exposed to pollutants (Bertrand et al., 2017; Dogan et al., 2018). On the contrary, the increase in pigment concentrations could be associated with an attempt of the macrophyte to maintain photosynthetic rates in water resources with high turbidity.

3.2.2.2. Antioxidant enzymes. Regarding antioxidant enzymes, once more, different patterns of response were observed at each monitoring site depending on the period of sampling, tissue or biomarker measured. When comparing the antioxidant enzymes

Table 2

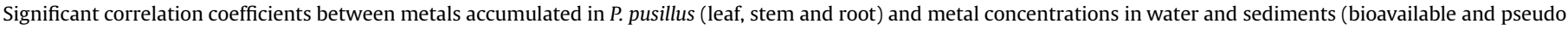
total fractions). Level of significance $={ }^{*} \mathrm{p}<0.05$ and ${ }^{* *}$ for $\mathrm{p}<0.01$.

\begin{tabular}{|c|c|c|c|c|c|c|c|c|}
\hline & & \multirow[b]{2}{*}{ Elements } & \multicolumn{3}{|l|}{$\mathrm{CP}$} & \multicolumn{3}{|l|}{ WP } \\
\hline & & & Leaf & Stem & Root & Leaf & Stem & Root \\
\hline \multirow[t]{7}{*}{ Water } & & Al & & & & $0.78^{*}$ & & \\
\hline & & As & $0.77^{*}$ & & & & $0.92^{* *}$ & \\
\hline & & Ba & & & & & $0.86^{*}$ & \\
\hline & & $\mathrm{Cr}$ & $0.94^{* *}$ & $0.43^{* *}$ & $0.87^{* *}$ & & & \\
\hline & & $\mathbf{P b}$ & & & & $0.84^{*}$ & & \\
\hline & & $\mathrm{Sr}$ & $0.82^{*}$ & & & & $0.91^{* *}$ & \\
\hline & & $\mathbf{V}$ & & $0.76^{*}$ & & & $0.99^{* *}$ & $0.77^{*}$ \\
\hline \multirow[t]{7}{*}{ Sediments } & Bioavailable fraction $(\mathrm{A} 1+\mathrm{A} 2)$ & Cd & & & & & & $0.85^{*}$ \\
\hline & & $\mathbf{P b}$ & & & & & & $0.76^{*}$ \\
\hline & & $\mathbf{V}$ & & & & $0.98^{* *}$ & & \\
\hline & & $\mathbf{Z n}$ & $0.89^{* *}$ & & $0.87^{* *}$ & & & \\
\hline & Pseudototalfraction & Co & & & $0.83^{*}$ & & & \\
\hline & & $\mathbf{V}$ & & & $0.88^{* *}$ & & & \\
\hline & & Zn & $0.82^{*}$ & & $0.78^{*}$ & & & \\
\hline
\end{tabular}


responses at S2-S7 with S1, a greater number of significant responses were observed for WP than for $\mathrm{CP}$, and they were measured in leaf and root (SM, Figure SM5).

GPx activity was not detected in leaf during the CP (SM, Figure SM5). However, in stem and root during CP a significant inhibition was detected at S7. Instead, in WP, this enzyme was inhibited in leaf at S4 and activated in root at S5, in both cases when compared to S1. Guaiacol peroxidases (POD) were also inhibited in root at S2 during CP when compared with S1. On the contrary during the WP, the POD activity was significantly induced only in leaf at S6. Finally, the activity of SOD increased significantly in leaf at S6 in CP and from S2 to S6 in WP, compared with S1. Conversely, in the stem, a significant decay of SOD activity was observed from S4 to S6, during the CP. Described results would be indicating the occurrence of significant oxidative stress in macrophyte exposed in Ctalamochita River, particularly in those sites with urban settlements (S4 and S6) as well as in those sites with an intense industrial and agricultural activities (S5 and S7).

\subsubsection{Integrated biomarkers response (IBR)}

The individual interpretation of biomarkers in field studies is complex due to the different patterns observed for each of them. Therefore, IBR was used as a tool to integrate and interpret responses obtained along the basin to achieve a comprehensive understanding of the biomonitor response (Fig. 3). The index was calculated with those biomarkers selected through discriminant analysis (SM- Table SM6). A Kruskal Wallis test revealed strong differences among monitored stations $(\mathrm{p}<0.0001)$. During both monitored periods, S5 and S6 showed the highest levels of macrophyte response or suffered stress. As it was expected, the reference site (S1) was the one with the lowest IBR value, despite being the site with higher RI and MPEC-Q during the $\mathrm{CP}$ mainly associated with $\mathrm{Hg}$ concentrations. Nevertheless, the bioavailable fraction represented less than $10 \%$ of the total concentration of $\mathrm{Hg}$, in the CP. This result would be pointing out limitations of RI to reflect bioavailable pollutants in the ecosystem. Moreover, the stressor response levels in $P$. pusillus increased along the basin from S1 to S5 or S6 with a slight or strong decay at S7 during CP and WP, respectively. The higher values of IBR in S5 and S6 could be associated with an increased complexity of pollutants mixture as a result of multi-sources discharges expected in both sites. Pollutants surpassing freshwater guidelines $(\mathrm{Ag}, \mathrm{Al}$, and $\mathrm{Hg}$ ) and highest values of [TPharW] in S6, could be responsible to induce an attempt by macrophyte to diminish toxicological effects through an increase of biological responses. In addition, in S5, S6, and S7 a significant metal enrichment in sediments (mainly $\mathrm{Cd}, \mathrm{Pb}, \mathrm{Hg}, \mathrm{Zn}$ and $\mathrm{Ag}$ ) due to human activities was observed during the $\mathrm{CP}$ (3.1.3.2). The higher conductivity and salinity described in the lower basin could be responsible forthe IBR decrease in S7, since those physicochemical parameters were described to promote variations in the speciation and bioavailability of pollutants (Luoma and Rainbow, 2008). By last, during both periods, S2 showed IBR values significantly increased compared with the reference site which indicates a significant impact of Santa Rosa de Calamuchita town on the aquatic biota also in the upper basin.

To the best of our knowledge, only few field studies performed with phytoplankton (Pereira et al., 2009; Liu et al., 2014) considered IBR as a tool to obtain a holistic overview of how pollutants mixtures affect photosynthetic organisms, and ultimately, to assess their usefulness for environmental biomonitoring in aquatic systems. According to previous studies, IBR is able to evidence stress levels in exposed organisms but also it could be interpreted as the capacity of them to cope with pollutants mixtures (Potet et al., 2018). Previous passive monitoring using Mytilus described strong stress levels in organisms with IBR values higher than nine (Bocquené et al., 2004). Even when inter-species comparisons of IBR values are not suitable due to variability in biological and physiological responses, $P$. pusillus surpassed mentioned value up to eleven. Pereira et al. (2009) described IBR values close to twenty when Ulva sp. suffered the highest stress level after being exposed in sites with strong metals pollution. A comparison between IBR values obtained from studies using the same genus, or others macrophytes would be more appropriate but, these IBR values are not available at the time of the present study. P. pusillus results are the first approach about its potentiality to be used as a useful tool for monitoring programs of aquatic ecosystems. Nevertheless, the limited studies available are pointing out the need of future field studies using the described methodology in photosynthetic organisms for a better understanding of obtained responses and their usefulness for biomonitoring. The final consequences of pollutants on aquatic plant communities are mostly unknown and should be explored (Coutris et al., 2011).

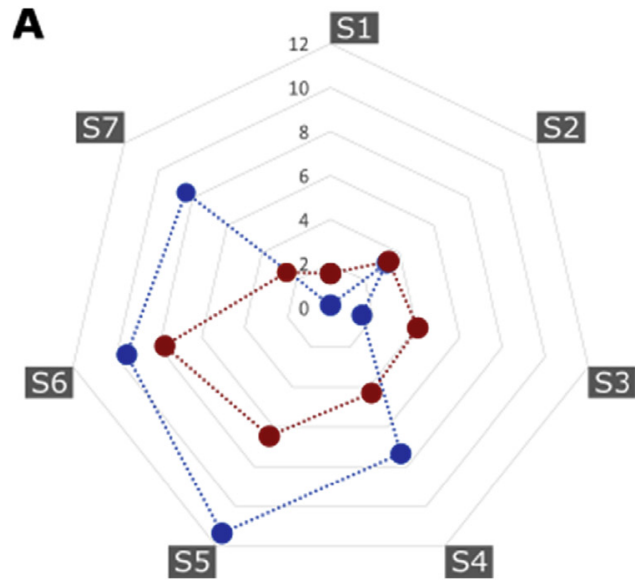

\begin{tabular}{|c|c|c|c|c|c|c|c|c|}
\hline \multirow{2}{*}{\multicolumn{9}{|c|}{ 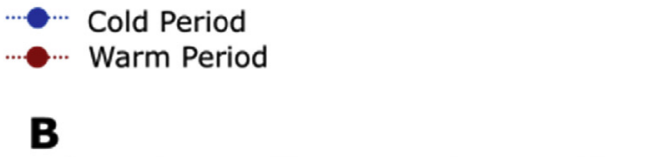 }} \\
\hline & & & & & & & & \\
\hline & \multicolumn{4}{|c|}{ Cold Period } & \multicolumn{4}{|c|}{ Warm Period } \\
\hline & Median & Min & $\operatorname{Max}$ & & Median & Min & $\operatorname{Max}$ & \\
\hline S1 & 0.0 & 0.0 & 0.3 & $\mathbf{a}$ & 1.5 & 1.2 & 1.8 & $\mathbf{a}$ \\
\hline S2 & 3.1 & 2.7 & 3.8 & c & 3.3 & 1.9 & 4.8 & c \\
\hline S3 & 1.4 & 0.8 & 2.1 & b & 4.0 & 2.8 & 5.2 & d \\
\hline S4 & 7.3 & 6.5 & 8.2 & d & 4.0 & 1.9 & 6.4 & d \\
\hline S5 & 11.3 & 10.3 & 12.3 & $\mathbf{g}$ & 6.0 & 4.2 & 8.9 & e \\
\hline S6 & 9.6 & 9.0 & 10.1 & f & 7.6 & 5.8 & 9.5 & $f$ \\
\hline 57 & 8.3 & 7.3 & 9.4 & e & 2.6 & 1.7 & 3.5 & b \\
\hline
\end{tabular}

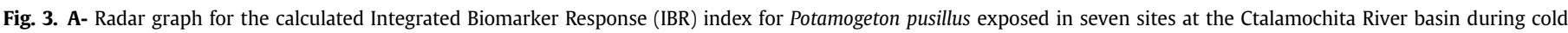

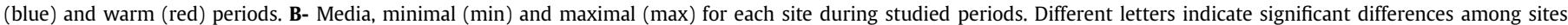

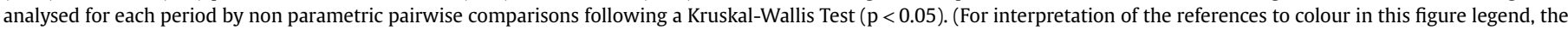
reader is referred to the Web version of this article.) 


\subsection{Multivariate analysis}

\subsubsection{Principal component analysis}

With the aim to investigate the associations between the macrophyte stress, or response, levels (IBR) and the environmental variables in the studied sites, a principal component analysis (PCA) was performed. The first four dimensions of PCA analysis explained the $94 \%$ and $95 \%$ of variability for CP and WP, respectively. Fig. 4 shows the biplot of PCA performed for the CP (A), where a $66.0 \%$ of the total inertia was explained by the first two axes. The monitoring sites are segregated into four groups or quadrants: I. including S6, which was associated with [TPharW], [TMetW] and IBR; showing the IBR a negative correlation with the WQI. II. including S5 and S7, which were associated with MPEC-Q, and RI. III. including the reference site (S1), showing a good association with WQI and low [TPharW] and [TMetW]. IV. including S2, S3 and S4 associated with the total metals in the bioavailable fraction [TBioS] and total metals in the pseudo-total fraction [TPsS] of the sediments.

In a similar way, in the WP the two first axes explained $74.3 \%$ of the total inertia (Fig. 4 B). The monitored sites were segregated in the following groups: I. S1 and S3, strongly associated with WQI, as well as with [TBioS] and [TPsS] toa lesser extent. II. Including S4 and S5, related with RI and MPEC-Q, as well as with IBR. III: including S6 associated with [TPharW] and [TMetW]. IV. Including S2 and S7, negatively associated with RI, MPEC-Q and IBR. To sum up, in both periods the reference site (S1) shows the best environmental quality and lowest stress levels for P. pusillus. On the contrary, S5, S6 and S7 in CP as well as S4, S5 and S6 in WP, show the highest IBR values for the macrophyte.

The PCA analysis consistently reflected a positive and significant association between the degree of biomonitor response and the concentrations of pharmaceuticals and metals in the environment, being this linkage strongest in the $\mathrm{CP}$ than WP, probably due to a greater pollutants levels. Harguinteguy et al. (2016) also reported an association between metal accumulation in $P$. pusillus through passive monitoring and sediment levels downstream Río Tercero city. However, the literature is limited for ecotoxicity data, especially on plants exposed to pharmaceuticals. The first results are promising considering that Lemna genus showed antioxidant response to chlorpromazine, paracetamol, and diclofenac (Alkimin et al., 2019). A higher understanding of the macrophyte response capacity to pharmaceutical compounds exposure will probably improve and promote the use of $P$. pusillus in monitoring programs of aquatic environments. Moreover, the quantification of other pollutants as pesticides and polycyclic aromatic hydrocarbons not available in the present study, would also help to characterize the biomonitor response.

\subsubsection{Multivariate regression analysis}

Finally, with the aim to evaluate those concentrations of pollutants with higher capacity to explain the stress suffered by exposed macrophytes, multivariate regression analysis (MRA) were fitted for both periods.

Firstly, we quantified the contribution of water metals and metalloids concentrations on the stress levels suffered by the biomonitor. Models showed a significant effect on the IBR value due to $\mathrm{Cr}>\mathrm{Cu}>\mathrm{Hg}>\mathrm{Al}>\mathrm{Pb}$ in $\mathrm{CP}$, and to $\mathrm{Pb}>\mathrm{Al}>\mathrm{As}>\mathrm{Cr}>\mathrm{Cu}$ during WP. Chromium and $\mathrm{Pb}$ were the parameters with higher influence on the IBR values during CP and WP, respectively (Table 3). The analysis of coefficients shows that the biomonitor response was boosted when exposure concentrations of $\mathrm{Cr}$ and $\mathrm{Pb}$ increased. As well as, the negative coefficients of $\mathrm{Pb}$ in $\mathrm{CP}$ and $\mathrm{As}, \mathrm{Cr}$, and $\mathrm{Cu}$ in WP, could probably indicate a decrease in the ability of the monitor to cope with pollutant mixture. According to the models, the $\mathrm{Cr}, \mathrm{Cu}$, $\mathrm{Hg}$, and $\mathrm{Al}$ during the $\mathrm{CP}$ as well as $\mathrm{Pb}$ and $\mathrm{Al}$ for the WP increased
A

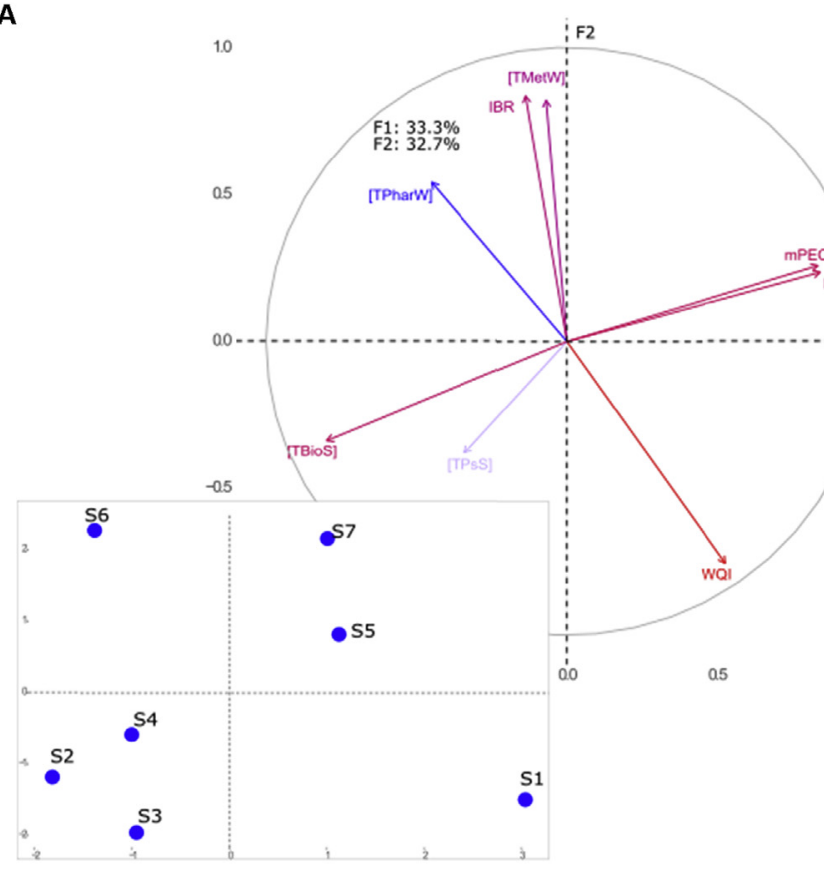

B

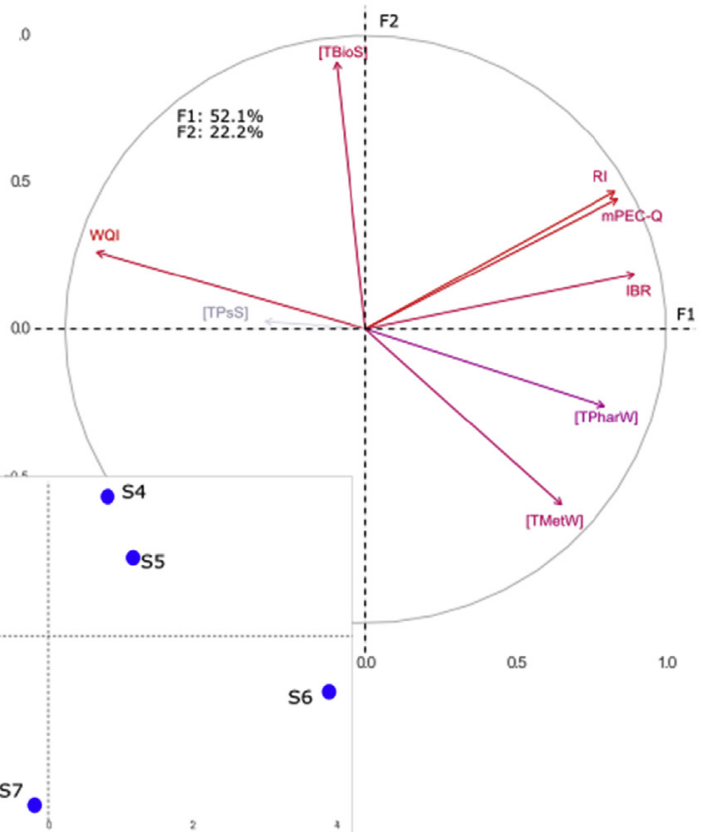

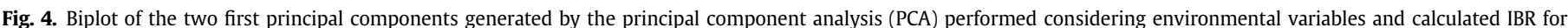

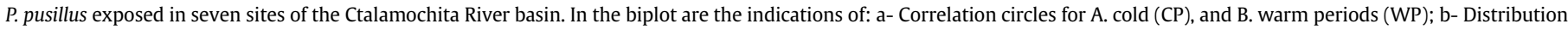

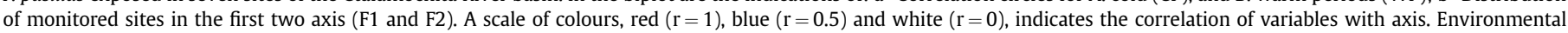

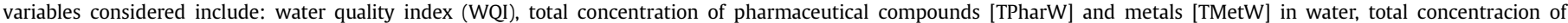

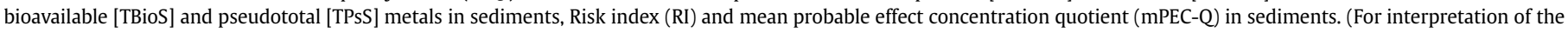
references to colour in this figure legend, the reader is referred to the Web version of this article.) 


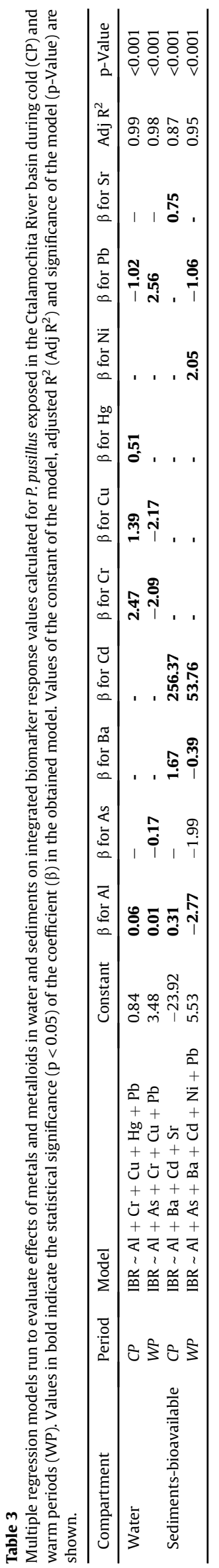

the IBR values observed along the basin; which would agree with surpassed environmental guidelines for aquatic biota protection, previously informed (Table $1 ; \mathrm{Al}, \mathrm{Pb}$ and $\mathrm{Hg}$ during $\mathrm{CP}$ as well as, $\mathrm{Al}$ and $\mathrm{Pb}$ during $\mathrm{WP}$ ) and described positive correlation between metals accumulation $(\mathrm{Cr}, \mathrm{Al}, \mathrm{Pb})$ and environmental levels (Table 2). Therefore, in this complex environmental scenario, P. pusillus was able to respond to some of these troublesome metals.

In a second instance, we evaluated the contribution of bioavailable elements concentrations in sediments on IBR value. Significant influence of elements decreased according to $\mathrm{Cd}>\mathrm{Ba}>\mathrm{Sr}>\mathrm{Al}$ during $\mathrm{CP}$, and $\mathrm{Cd}>\mathrm{Ni}>\mathrm{Ba}>\mathrm{Pb}>\mathrm{Al}$ for WP. For both periods, the cadmium was the metal with higher significant effect on IBR values. Most of the coefficients were negative in WP $(\mathrm{Al}, \mathrm{Ba}$, and $\mathrm{Pb})$ which could be associated with lower concentrations of metals and metalloids in sediments during this period. Accordingly, if EF, mPEC and RI are considered, concentrations of elements and the associated risk, decreased during WP in the studied basin compared with CP.

It is important to point out that elements like $\mathrm{Ag}$ and B were ruled out the model due high collinearity with others variables, probably indicating a limitation of the analysis, at least from a statistical point of view.

\section{Conclusions}

The present study is one of the few studies, and the first one using Potamogeton genus, evaluating through an active monitoring procedure the ability of freshwater macrophytes as biomonitors. Through the presented results, it was possible to evidence the potentiality and usefulness of $P$. Pusillus to be used as a biomonitor highlighting the pollution hotspots of aquatic ecosystems.

The environmental scenario of Ctalamochita River basin confirmed a significant decay in environmental quality along the basin with the worst conditions in those sites located downstream the main cities. The results of the present study evidenced a significant anthropogenic impact on the aquatic ecosystem and possible water uses. This impact was demonstrated by surpassed environmental quality guidelines, and also by the obtained EF and RI values calculated for sediments. The severe $\mathrm{Hg}$ contamination, as well as $\mathrm{Ag}, \mathrm{Cd}, \mathrm{Pb}, \mathrm{Zn}, \mathrm{Cu}$ and $\mathrm{Cr}$ concentrations in the Ctalamochita River basin confirms the need for an environmental management of the water resource.

Potamogeton pusillus, showed sensitivity to pollutants mixture pointing out those sites with lower environmental quality during both studied periods. The IBR confirmed, once more, to be a useful tool to obtain a holistic interpretation of response, or stress, levels suffered by organism. A positive association was observed between IBR values and analysed pollutants in environmental matrices, mainly in $\mathrm{CP}$ where higher concentrations of contaminants were measured. Concentrations of metals, like $\mathrm{Cr}, \mathrm{Cu}, \mathrm{Hg}, \mathrm{Al}$ and $\mathrm{Cd}$, displayed significant effect on biomonitor response which was in concordance with the described decay in environmental quality along the basin. The present study confirmes the complexity to evaluate the impact of pollutants mixture on aquatic biota. As it was showed, chemicals analysis are not enough to evaluate environmental quality and risk index or enrichments factors are not always able to reflect bioavailability and therefore, toxicological effects on organisms. Finally, future field studies promoting the use of macrophytes as biomonitor will be suitable for the development of environmental management tools, like active biomonitoring programs, for multi-source contaminated scenarios.

\section{Acknowledgements}

This work was supported by grants from the Agencia Nacional 
de Promoción Científica y Técnica (FONCyT-PICT/; 2013-1348 and 2015-1784) and Secretaría de Ciencia y Técnica (SECyT). The present work is part of the PhD thesis of L. Bertrand, who gratefully acknowledges fellowship from CONICET.

\section{Appendix A. Supplementary data}

Supplementary data to this article can be found online at https://doi.org/10.1016/j.chemosphere.2019.02.018.

\section{References}

AEWQG, 2003. ArgentineanEnvironmentalWaterQualityGuidelines; Niveles Guía Nacionales de Calidad de Agua Ambiente). Subsecretaria de Recursos Hídricos de la Nación, República Argentina.

Aiassa, V., Barnes, A.I., Albesa, I., 2010. Resistance to ciprofloxacin by enhancement of antioxidant defences in biofilm and planktonic Proteus mirabilis. Biochem. Biophys. Res. Commun. 393, 84-88. https://doi.org/10.1016/j.bbrc.2010.01.083.

Alkimin, G.D., Daniel, D., Frankenbach, S., Serôdio, J., Soares, A.M.V.M., Barata, C., Nunes, B., 2019. Evaluation of pharmaceutical toxic effects of non-standard endpoints on the macrophyte species Lemna minor and Lemna gibba. Sci. Total Environ. 657, 926-937. https://doi.org/10.1016/j.scitotenv.2018.12.002.

APHA (American Public Health Association), 1998. Standard Methods for the Examination of Water and Wastewater, twentieth ed. ed. American Public Health Organization, Washington, D.C. USA.

Ballesteros, M.L., Rivetti, N.G., Morillo, D.O., Bertrand, L., Amé, M.V., Bistoni, M.A 2017. Multi-biomarker responses in fish (Jenynsiamultidentata) to assess the impact of pollution in rivers with mixtures of environmental contaminants. Sci. Total Environ. 595, 711-722. https://doi.org/10.1016/j.scitotenv.2017.03.203.

Beliaeff, B., Burgeot, T., 2002. Integrated Biomarker Response: a useful tool for ecological risk assessment. Environ. Toxicol. Chem. 21, 1316-1322.

Bergmeyer, H.U., 1983. Methods of Enzymatic Analysis, vol. I. VCH Weinheim, Germany, pp. 648-653.

Bertrand, L., Asis, R., Monferrán, M.V., Amé, M.V., 2016. Bioaccumulation and biochemical response in South American native species exposed to zinc: boosted regression trees as novel tool for biomarkers selection. Ecol. Indicat. 67, 769-778. https://doi.org/10.1016/j.ecolind.2016.03.048.

Bertrand, L., Marino, D.J., Monferrán, M.V., Amé, M.V., 2017. Can a low concentration of an organophosphate insecticide cause negative effects on an aquatic macrophyte? Exposure of Potamogetonpusillus at environmentally relevant chlorpyrifos concentrations. Environ. Exp. Bot. 138, 139-147. https://doi.org/ 10.1016/j.envexpbot.2017.03.006.

Bertrand, L., Monferrán, M.V., Mouneyrac, C., Amé, M.V., 2018. Native crustacean species as a bioindicator of freshwater ecosystem pollution: a multivariate and integrative study of multi-biomarker response in active river monitoring Chemosphere 206, 265-277. https://doi.org/10.1016 j.chemosphere.2018.05.002.

Besse, J.P., Geffard, O., Coquery, M., 2012. Relevance and applicability of active biomonitoring in continental waters under the Water Framework Directive. TrAC Trends Anal. Chem. (Reference Ed.) 36, 113-127. https://doi.org/10.1016/ j.trac.2012.04.004.

Bocquené, G., Chantereau, S., Clérendeau, C., Beausir, E., Ménard, D., Raffin, B. Minier, C., Burgeot, T., Leszkowicz, A.P., Narbonne, J.-F., 2004. Biological effects of the" Erika" oil spill on the common mussel(Mytilus edulis). Aquat. Living Resour. 17, 309-316. https://doi.org/10.1051/alr.

Bonanno, G., Borg, J.A., Di Martino, V., 2017. Levels of heavy metals in wetland and marine vascular plants and their biomonitoring potential: a comparative assessment. Sci. Total Environ. 576, 796-806. https://doi.org/10.1016/ j.scitotenv.2016.10.171.

Bradford, M.M., 1976. A rapid and sensitive method for the quantification of microgram quantities of proteins utilizing the principle of protein-dye binding. Anal. Biochem. 72, 248-254.

Brain, R. a, Johnson, D.J., Richards, S.M., Sanderson, H., Sibley, P.K., Solomon, K.R. 2004. Effects of 25 pharmaceutical compounds to Lemnagibba using a sevenday static-renewal test. Environ. Toxicol. Chem. 23, 371-382. https://doi.org 10.1897/02-576.

Ciliberti, A., Chaumot, A., Recoura-Massaquant, R., Chandesris, A., Francois, A Coquery, M., Ferréol, M., Geffard, O., 2017. Caged Gammarus as biomonitors identifying thresholds of toxic metal bioavailability that affect gammarid densities at the French national scale. Water Res. 118, 131-140. https://doi.org 10.1016/j.watres.2017.04.031.

Clara, M., Strenn, B., Kreuzinger, N., 2004. Carbamazepine as a possible anthropogenic marker in the aquatic environment: Investigations on the behaviour of Carbamazepine in wastewater treatment and during groundwater infiltration. Water Res. 38, 947-954. https://doi.org/10.1016/j.watres.2003.10.058.

Cleuvers, M., 2005. Initial risk assessment for three $\beta$-blockers found in the aquatic environment. Chemosphere 59, 199-205. https://doi.org/10.1016 j.chemosphere.2004.11.09.

Costa, M.B., Tavares, F.V., Martinez, C.B., Colares, I.G., Martins, C. de M.G., 2018. Accumulation and effects of copper on aquatic macrophytes Potamogetonpectinatus L.: potential application to environmental monitoring and phytoremediation. Ecotoxicol. Environ. Saf. 155, 117-124. https://doi.org/ 10.1016/j.ecoenv.2018.01.062.

Coutris, C., Merlina, G., Silvestre, J., Pinelli, E., Elger, A., 2011. Can we predict community wide effects of herbicides from toxicity tests on macrophyte species? Aquat. Toxicol. 101, 49-56. https://doi.org/10.1016/j.aquatox.2010.08.017.

Demirezen, D., Aksoy, A., 2004. Accumulation of heavy metals in Typha angustifolia (L.) and Potamogeton pectinatus (L.) living in sultan marsh (kayseri, Turkey). Chemosphere 56, 685-696. https://doi.org/10.1016/j.chemosphere.2004.04.011.

de Sousa, D.N.R Mozeto, A.A Carneiro, R. Fadini, PS, 2014. Electrical conductivity and emerging contaminant as markers of surface freshwater contamination by wastewater. Sci. Total Environ. 484, 19-26. https://doi.org/10.1016/ j.scitotenv.2014.02.135.

Di Rienzo, J.A., Casanoves, F., Balzarini, M.G., Gonzalez, L., Tablada, M., Robledo, C.W., 2017. InfoStat Versión 2017. Grupo InfoStat, FCA. Universidad Nacional de Córdoba, Argentina. http://www.infostat.com.ar.

DiPAS, UNC, 2007. Estudio de contaminación del Río Tercero (Ctalamochita) y control de vertidos. Primer Informe.

Dogan, M., Karatas, M., Aasim, M., 2018. Cadmium and lead bioaccumulation potentials of an aquatic macrophyte Ceratophyllumdemersum L.: a laboratory study. Ecotoxicol. Environ. Saf. 148, 431-440. https://doi.org/10.1016/ j.ecoenv.2017.10.058

Drotar, A., Phelps, P., Fall, R., 1985. Evidence for glutathione peroxidase activities in cultured plant cells. Plant Sci. 42, 35-40.

Duman, F., Obali, O., Demirezen, D., 2006. Seasonal changes of metal accumulation and distribution in shining pondweed (Potamogetonlucens). Chemosphere 65, 2145-2151. https://doi.org/10.1016/j.chemosphere.2006.06.036.

Duman, F., Cicek, M., Sezen, G., 2007. Seasonal changes of metal accumulation and distribution in common club rush (Schoenoplectuslacustris) and common reed (Phragmites australis). Ecotoxicology 16, 457-463. https://doi.org/10.1007/ s10646-007-0150-4.

Elorriaga, Y., Marino, D.J., Carriquiriborde, P., Ronco, A.E., 2013. Screening of pharmaceuticals in surface water bodies of the Pampas region of Argentina. Int. J. Environ. Health 6, 330-339. https://doi.org/10.1504/IJENVH.2013.056974.

Garanzini, D.S., Menone, M.L., 2015. Azoxystrobin causes oxidative stress and DNA damage in the aquatic macrophyte myriophyllumquitense. Bull. Environ. Contam. Toxicol. 94, 146-151. https://doi.org/10.1007/s00128-014-1428-x.

Gavrilescu, M., Demnerová, K., Aamand, J., Agathos, S., Fava, F., 2015. Emerging pollutants in the environment: present and future challenges in biomonitoring, ecological risks and bioremediation. N. Biotech. 32, 147-156. https://doi.org/ 10.1016/j.nbt.2014.01.001.

Ghisi, N.C., Oliveira, E.C., Guiloski, I.C., de Lima, S.B., Silva de Assis, H.C., Longhi, S.J., Prioli, A.J., 2017. Multivariate and integrative approach to analyze multiple biomarkers in ecotoxicology: a field study in Neotropical region. Sci. Total Environ. 609, 1208-1218. https://doi.org/10.1016/j.scitotenv.2017.07.266.

Ghrefat, H.A., Abu-rukah, Y., Rosen, M.A., 2011. Application of geoaccumulation index and enrichment factor for assessing metal contamination in the sediments of KafrainDam , Jordan. Environ. Monit. Assess. 178, 95-109. https:// doi.org/10.1007/s10661-010-1675-1.

Gonzalez, M., Miglioranza, K.S.B., Grondona, S.I., Barni, M.F.S., Martinez, D.E., Peña, A., 2013. Organic pollutant levels in an agricultural watershed: the importance of analyzing multiple matrices for assessing streamwater pollution. Environ. Sci.: Process. Impacts 739-750. https://doi.org/10.1039/c3em30882k.

Hakanson, L., 1980. An ecological risk index for aquatic pollution control. Asedimentological approach. Water Res. 14, 975-1001. https://doi.org/10.1016/00431354(80)90143-8.

Harguinteguy, C.A., Cofré, N., Fernández-Cirelli, A., Luisa Pignata, M., 2016. The macrophytes Potamogetonpusillus L. and Myriophyllumaquaticum (Vell.) Verdc. as potential bioindicators of a river contaminated by heavy metals. Microchem. J. 124, 228-234. https://doi.org/10.1016/j.microc.2015.08.014.

Klute, A., 1986. Methods of Soil Analysis I. Physical and Mineralogical Methods. American Society of Agronomy and Soil Science WI, Madison.

Kummerová, M., Zezulka, Š., Babula, P., Tříska, J., 2016. Possible ecological risk of two pharmaceuticals diclofenac and paracetamol demonstrated on a model plant Lemna minor. J. Hazard Mater. 302, 351-361. https://doi.org/10.1016/ j.jhazmat.2015.09.057.

Li, F., Fan, Z., Xiao, P., Oh, K., Ma, X., Hou, W., 2009. Contamination, chemical speciation and vertical distribution of heavy metals in soils of an old and large industrial zone in Northeast China. Environ. Geol. 57, 1815-1823. https:// doi.org/10.1007/s00254-008-1469-8.

Liu, J.L., Yang, Y., Liu, F., Zhang, L.L., 2014. Relationship between periphyton biomarkers and trace metals with the responses to environment applying an integrated biomarker response index (IBR) in estuaries. Ecotoxicology 23, 538-552. https://doi.org/10.1007/s10646-014-1234-6.

Long, E.R., Ingersoll, C.G., MacDonald, D.D., 2006. Calculation and uses of mean sediment quality guideline quotients: a critical review. Environ. Sci. Technol. 40, 1726-1736. https://doi.org/10.1021/es058012d.

Luoma, S.N., Rainbow, P.S., 2008. Metal Contamination in Aquatic Environments. Science and Lateral Management. Cambridge University Press, New York, USA, p. 573.

MacDonald, D.D., Ingersoll, C.G., Berger, T.A., 2000. Development and evaluation of consensus-based sediment quality guidelines for freshwater ecosystems. Arch. Environ. Contam. Toxicol. 39, 20-31. https://doi.org/10.1007/s002440010075.

Maranho, L.A., Pereira, C.D.S., 2017. Chapter 33. Pharmaceutical and personal care products (PPCPS) in the environment: Latin American occurrences, adverse effects and perspectives. In: Araújo, C.V.M., Shinn, C. (Eds.), Ecotoxicology in 
Latin America. Nova Science Publishers, pp. 537-549.

Merlo, C., Abril, A., Ame, M.V., Arguello, G.A., Carreras, H.A., Chiappero, M.S. Hued, A.C., Wannaz, E., Galanti, L.N., Monferran, M.V., Gonzalez, C.M. Solis, V.M., 2011. Integral assessment of pollution in the Suquia River (Cordoba, Argentina) as a contribution to lotic ecosystem restoration programs. Sci. Total Environ, 409, 5034-5045.

Mertens, J., Luyssaert, S., Verheyen, K., 2005. Use and abuse of trace metal concentrations in plant tissue for biomonitoring and phytoextraction. Environ. Pollut. 138, 1-4. https://doi.org/10.1016/j.envpol.2005.01.002.

Miège, C., Choubert, J.M., Ribeiro, L., Eusèbe, M., Coquery, M., 2009. Fate of pharmaceuticals and personal care products in wastewater treatment plants conception of a database and first results. Environ. Pollut. 157, 1721-1726. https://doi.org/10.1016/j.envpol.2008.11.045.

Monferrán, M.V., Agudo, J.A.S., Pignata, M.L., Wunderlin, D.A., 2009. Copper-induced response of physiological parameters and antioxidant enzymes in the aquatic macrophyte Potamogetonpusillus. Environ. Pollut. 157, 2570-2576. https:// doi.org/10.1016/j.envpol.2009.02.034.

Munteanu, V., Munteanu, G., 2007. Biomonitoring of mercury pollution: a case study from the Dniester River. Ecol. Indicat. 7, 489-496. https://doi.org/10.1016/ j.ecolind.2006.01.002.

Müller, G., 1979. Schwermetalle in den sedimenten des Rheins - VeraE‘ nderungenseit 1971. Umschau 79, 778-783.

Nichols, S.A., Shaw, B.H., 1986. Ecological life histories of the three aquatic nuisance plants, Myriophyllum spicatum, Potamogeton crispus and Elodea canadensis Stanley. Hydrobiologia 131, 3-21.

Nimptsch, J., Wunderlin, D., Dollan, A., Pflugmacher, S., 2005. Antioxidant and biotransformation enzymes in Myriophyllumquitense as biomarkers of heavy metal exposure and eutrophication in Suquía River basin (Córdoba, Argentina). Chemosphere 61, 147-157. https://doi.org/10.1016/j.chemosphere.2005.02.079.

Novara, N.J., 2003. Potamogetonaceaedumort. In: Flora del valle de Lerma. Aportes Botánicos de Salta. Serie Flora, vol. 7, p. 14

O'Brien, J.M., Lessard, J.L., Plew, D., Graham, S.E., McIntosh, A.R., 2014. Aquatic macrophytes alter metabolism and nutrient cycling in lowland streams. Ecosystems 17, 405-417. https://doi.org/10.1007/s10021-013-9730-8.

O'Mill, P., 2012. Evaluación de la calidad del agua del Río Tercero (Ctalamochita), Córdoba, utilizando biomarcadores en Limnopernafortunei. Universidad Nacional de Córdoba.

Ondarza, P.M., Haddad, S.P., Avigliano, E., Miglioranza, K.S.B., Brooks, B.W., 2019. Pharmaceuticals, illicit drugs and their metabolites in fish from Argentina: implications for protected areas influenced by urbanization. Sci. Total Environ. 649, 1029-1037. https://doi.org/10.1016/j.scitotenv.2018.08.383.

Pasquini, A.I., Formica, S.M., Sacchi, G., 2011. Hydrochemistry and nutrients dynamic in the Suquía River urban catchment's, Córdoba, Argentina. Environ. Earth Sci. 65 (2), 453-467. https://doi.org/10.1007/s12665-011-0978-z.

Pereira, P., de Pablo, H., Rosa-Santos, F., Pacheco, M., Vale, C., 2009. Metal accumulation and oxidative stress in Ulva sp. substantiated by response integration into a general stress index. Aquat. Toxicol. 91, 336-345. https://doi.org/10.1016/ j.aquatox.2008.12.003.

Pérez, D.J., Okada, E., Menone, M.L., Costa, J.L., 2017. Can an aquatic macrophyte bioaccumulate glyphosate? Development of a new method of glyphosate extraction in Ludwigia peploides and watershed scale validation. Chemosphere 185, 975-982. https://doi.org/10.1016/j.chemosphere.2017.07.093.

Pesce, S.F., Wunderlin, D.A., 2000. Use of water quality indices to verify the impact of Córdoba City (Argentina) on Suquía River. Water Res. 34 (11), 2915-2926. https://doi.org/10.1016/S0043-1354(00)00036-1.

Potet, M., Giambérini, L., Pain-Devin, S., Louis, F., Bertrand, C., Devin, S., 2018. Differential tolerance to nickel between Dreissenapolymorpha and Dreissenarostriformisbugensis populations. Sci. Rep. 8, 700. https://doi.org/10.1038/s41598018-19228-X.

Quadra, G.R., Oliveira de Souza, H., Costa, R.S., Fernandez, M.A.S., 2017. Do pharmaceuticals reach and affect the aquatic ecosystems in Brazil? A critical review of current studies in a developing country. Environ. Sci. Pollut. Control Ser. 24 (2), 1200-1218. https://doi.org/10.1007/s11356-016-7789-4.

Ronci, L., Meccoli, L., Iannilli, V., Menegoni, P., Matthaeis, E. De, Setini, A., Meccoli, L., Iannilli, V., Menegoni, P., Matthaeis, E. De, Setini, A., 2016. Comparison between active and passive biomonitoring strategies for the assessment of genotoxicity and metal bioaccumulation in Echinogammarus veneris (Crustacea: Amphipoda). Ital. J. Zool. 83, 162-172. https://doi.org/10.1080/11250003.2016.1169321.

Ruchter, N., Sures, B., 2015. Distribution of platinum and other traffic related metals insediments and clams (Corbicula sp.). Water Res. 70, 313-324. https://doi.org/ 10.1016/j.watres.2014.12.011.

Sneddon, L.U., Halsey, L.G., Bury, N.R., 2017. Considering aspects of the 3Rs principles within experimental animal biology. J. Exp. Biol. 220 (17), 3007-3016. https://doi.org/10.1242/jeb.147058.

Tan, Q.G., Zhou, W., Wang, W.X., 2018. Modeling the Toxicokinetics of Multiple Metals in the Oyster Crassostrea hongkongensis in a Dynamic Estuarine Environment. Environ. Sci. Technol. 52, 484-492. https://doi.org/10.1021/ acs.est.7b04906.

USEPA, 1988. Ambient Water Quality Criteria for Aluminum. Environmental Protection Agency. https://nepis.epa.gov/Exe/ZyPDF.cgi/2000M5FC.PDF? Dockey $1 / 42000$ M5FC.PDF. (Accessed 26 February 2018).

Valdés, M.E., Amé, M.V., Bistoni, M. de los A., Wunderlin, D.A., 2014. Occurrence and bioaccumulation of pharmaceuticals in a fish species inhabiting the Suquía River basin (Córdoba, Argentina). Sci. Total Environ. 472, 389-396. https:// doi.org/10.1016/j.scitotenv.2013.10.124.
Valdés, M.E., Huerta, B., Wunderlin, D.A., Bistoni, M.A., Barceló, D., RodriguezMozaz, S., 2016. Bioaccumulation and bioconcentration of carbamazepine and other pharmaceuticals in fish under field and controlled laboratory experiments. Evidences of carbamazepine metabolization by fish. Sci. Total Environ. 557-558, 58-67. https://doi.org/10.1016/j.scitotenv.2016.03.045.

Wetzel, R.G., 2001. In: Limnology: Lake and River Ecosystems, Third ed. Academic Press Elsevier, San Diego, USA.

Wintermans, J.F., de Mots, A., 1965. Spectrophotometric characteristics of chlorophylls $\mathrm{a}$ and $\mathrm{b}$ and their pheophytins in ethanol. Biochim. Biophys. Acta 109, 448-453. https://doi.org/10.1016/0926-6585(65)90170-6.

Xu, Q.S., Hu, J.Z., Xie, K.B., Yang, H.Y., Du, K.H., Shi, G.X., 2010. Accumulation and acute toxicity of silver in Potamogetoncrispus L. J. Hazard Mater. 173, 186-193. https://doi.org/10.1016/j.jhazmat.2009.08.067.

Yang, J., Chen, L., Liu, L., Shi, W., Mengn, X., 2014. Comprehensive risk assessment of heavy metals in lake sediment from public parks in Shanghai. Ecotoxicol. Environ. Saf. 102, 129-135. https://doi.org/10.1016/j.ecoenv.2014.01.010.

Yi, Y., Yang, Z., Zhang, S., 2011. Ecological risk assessment of heavy metals in sediment and human health risk assessment of heavy metals in fishes in the middle and lower reaches of the Yangtze River basin. Environ. Pollut. 159, 2575-2585. https://doi.org/10.1016/j.envpol.2011.06.011.

\section{Abbreviations}

$\left[\mathrm{NH}_{4}\right]^{+}$: ammonia nitrogen

$\left[\mathrm{NO}_{2}\right]^{-}$: nitrites nitrogen

$\left[\mathrm{NO}_{3}\right]^{-}$: nitrates nitrogen

[TBioS]: Total concentration in the bioavailable fraction in sediments of metals/ metalloids

[TMetW]: Total concentration in water of metals/metalloids

[TPharW]: Total concentration in water of pharmaceutical compounds

[TPSS]: Total concentration in the pseudototal fraction in sediments of metals metalloids

A1: mobile fraction

A2: mobilisable fraction

AEWQG: Argentinean Environmental Water Quality Guidelines

AND: androstenedione

ATE: atenolol

CBZ: carbamazepine

Chl: Chlorophyll

CIPR: ciprofloxacin

CLAR: clarithromycin

$C P$ : Cold Period

CRMs: certified reference materials

$C W$ : Warm Period

$D A$ : Discriminant analysis

DHT: dihydrotestosterone

$d w$ : dry weight

$E_{1}$ : estrogens: $17 \beta$-estradiol

$E_{2}$ : estrone

EF: enrichment factor

ENAL:: enalapril

$G P x$ : glutathione peroxidase

HPLC-ESI-qTOF: Liquid chromatography coupled to mass spectrometry using a quadrupole time-of-flight analyzer, with an electrospray ionization source

IBR: Integrated Biomarker Response

ICP-MS: Mass Spectrometer Inductively Coupled Plasma

Igeo: geoaccumulation index

LOD: limit of the detection

$L O Q$ : limit of quantification

$M D L::$ method detection limit

MLRM: multiple linear regression models

$m P E C-Q::$ mean probable effect concentration quotient

$M P N$ : most probable number

MT: methyltestosterone

NBT: p-nitroblue tetrazolium chloride

OXCZ: oxcarbazepine

$P C A$ : principal component analysis

PEC: probable effect concentrations

Pheo: Pheophytins

POD: guaiacol peroxidase

PROP: propranolol

Ps: pseudo-total fraction

QA: Quality assurance

QC: quality control

RI: ecological risk index

SM: Supplementary Material

SOD: Superoxide dismutase

SQGs: sediment quality guidelines

$T$ : testosterone

TEC: threshold effect concentrations

USEPA: United States Environmental Protection Agency

WQI: water quality index

ww: wet weight 